\title{
INFLUÊNCIA DA APLICAÇÃO DE COMPOSTO \\ DE LIXO URBANO NA CANA-DE-AÇÚCAR (Saccharum spp) E NA FERTILIDADE DO SOLO
}

ARIOVALDO FAUSTINO SOARES DA SILVA

Engenheiro Agrònomo

Orientador: Prof. Dr. MARCO ANTONIO AZEREDO CESAR

Dissertação apresentada à Escola Superior de Agricultura "Luiz de Queiroz", da Universidade de São Paulo, para obtenção do título de Mestre em Ciências, Área de concentração: Ciência e Tecnologia de Alimentos.

\author{
PIRACICABA \\ Estado de Sào Paulo - Brasil \\ Março - 1999
}


Dados Internacionais de Catalogação na Publicação (CIP) DIVISÃo DE BIBLIOTECA E DOCUMENTAÇÃO - Campus "Luiz de Oueiroz"/USP

Silva, Ariovaldo Faustino Soares da

Influência da aplicação de composto de lixo urbano na cana-de-açúcar (Saccharum

spp) e na fertilidade do solo / Ariovaldo Faustino Soares da Silva. - Piracicaba, 1999.

$70 \mathrm{p}$.

Dissertação (mestrado) - Escola Superior de Agricultura Luiz de Queiroz, 1999.

Bibliografia.

1. Adubo de lixo 2. Adubo orgànico 3. Cana-de-açúcar 4. Compostagem 5.

Fertilidade do solo 6. Residuo urbano I. Titulo

CDD 633.61

"Permitida a cópia total ou parcial deste documento, desde que citada a fonte-O Autor" 
Aos meus pais, Ayrton (in memorian) e Cremilde

DEDICO 


\section{AGRADECIMENTOS}

À todos que contribuíram para a realização deste trabalho, em especial:

- Ao Prof. Dr. Marco Antonio Azeredo Cesar, por me conceder a oportunidade, pela dedicação e atenção dispensadas;

- Ao Dr. Fábio Cesar da Silva, que muito me apoiou, dedicou e assistiu na elaboração e confecção da presente dissertação;

- $\quad$ Ao Prof. Dr. Jorge Horii;

- A Rubens Cesar Pereira, Sylvino Torrezan e Luiz Carlos Rodrigues;

- A Nazareno Travagline Junior, Leandro Cesar Bizelli; Beatriz Mastrodi, Carlos A.

F. Ribeiro e Hilkias Arruda Nicolau, André Vinicius Sesso;

- $\quad$ A Gislaine Maria Martins Nóbilo; Regina Lúcia de M. Loureiro e Rosemary L. S Mandro;

- Á Constante Christofoletti, Eduardo Giovani Arthuso, Pedro Dorival Lucentini, Pedro Rossini Filho e Wilson Januário e Benedito Araújo;

- Ao Departamento de Agroindústria, Alimentos e Nutrição da Escola Superior de Agricultura "Luiz de Queiroz" da Universidade de Sào Paulo, pela oportunidade concedida;

- Ao CNPq, pelo auxílio concedido na forma de Bolsa de Estudos, e da oportunidade de integrar às atividades de pesquisa do projeto integrado (Processo $350162 / 97-2)$. 


\section{SUMÁRIO}

\section{Páşina}

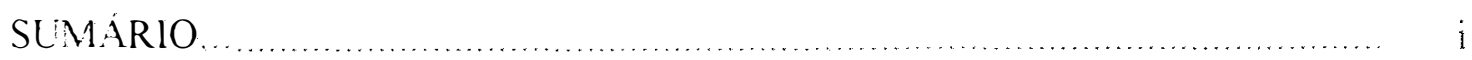

LISTA DE FIGURAS .................................................................. iv

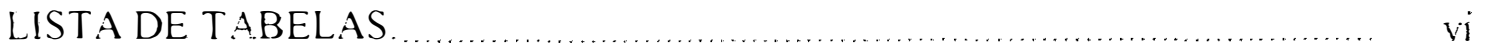

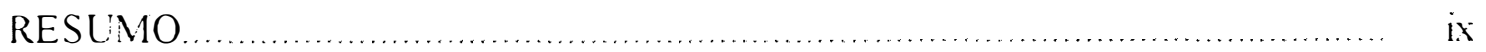

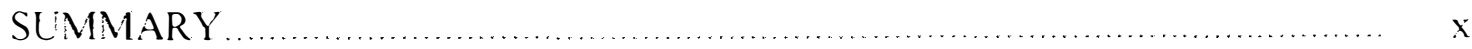

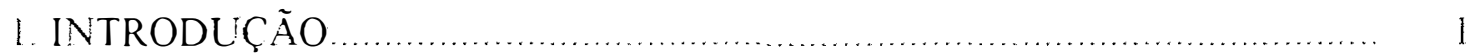

2. REVISÃO DE LITERATURA

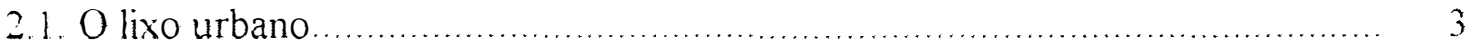

2.1. 1. Conceito e destino ...............................................................

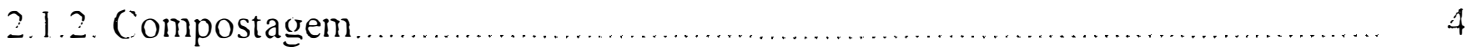

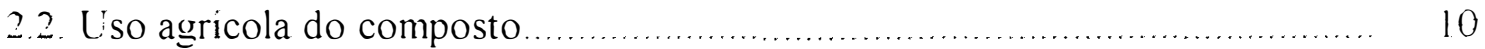

2.3. Potencialidade de Uso de Materiais Orgânicos (Composto de Lixo) na Cultura de Cana-de-Açúcar................................................................... 15

2.3.1. Efeitos benéficos da adição de matéria orgânica ao solos e resposta da cultura de cana-de-açúcar à aplicação de fontes orgânicas de nutrientes............... 15

23.2. Efeito de matéria orgânica e do potássio na qualidade tecnológica da canade-açucar: análise de riscos à maturação pela adição de composto de lixo... 16

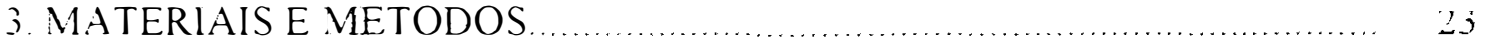

31. Caracteristicas gerais do local do composto de lixo domiciliar e do cultivar

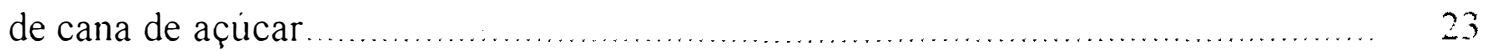

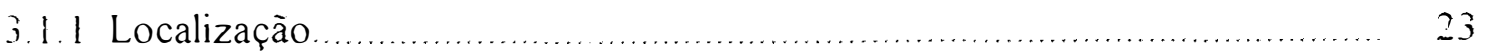




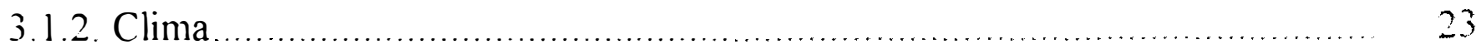

3. 1.3. Caracteristicas de fertilidade do solo............................................. 23

3.1.4. Composição do composto de lixo.................................................... 24

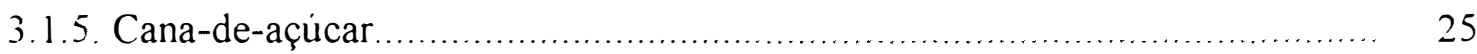

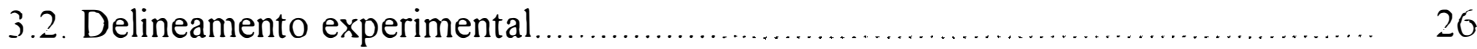

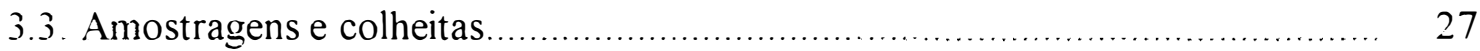

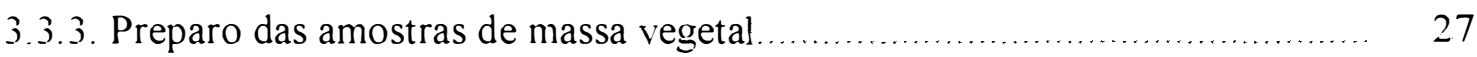

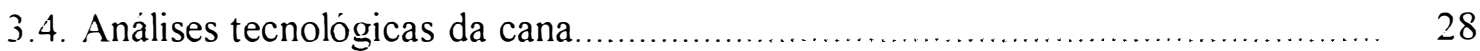

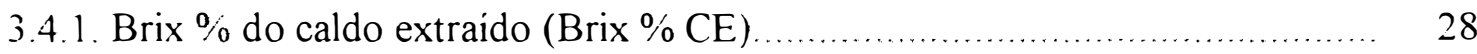

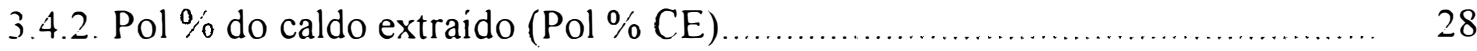

3.4.3. Pureza aparente \% do caldo extraido - calculado ( $\mathrm{Pu} \% \mathrm{CE}) \ldots \ldots \ldots \ldots \ldots \ldots . . . \ldots . . . . .28$

3.4.4. Açúcares redutores \% caldo extraido (AR \% CE) .............................. 28

3.4.5. Cinzas \% caldo extraio (Cinzas \% CE) ............................................ 28

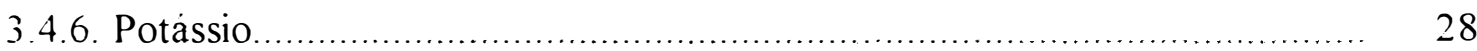

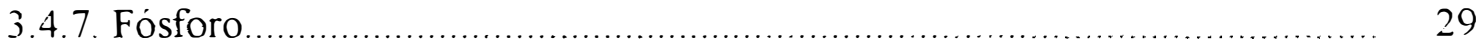

3.5. Transformação dos resultados \%caldo em \%cana................................... 29

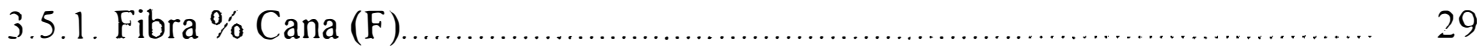

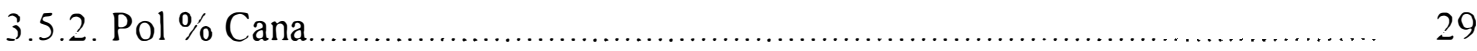

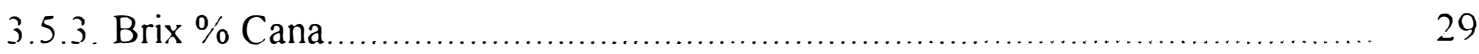

3.5.4. Açúcares Redutores \% Cana (AR\%Cana) .......................................... 30

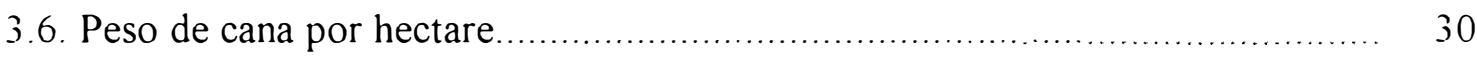

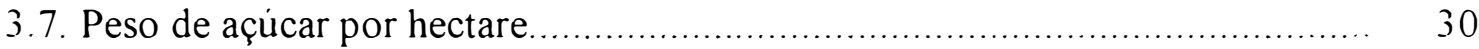

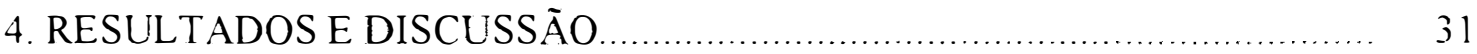

4.1. Condições Agrometeorológicas durante o Experimento............................ 31

4.2. Composto de Lixo: Composição e Legislação........................................... 31

4.3. Composto de Lixo Urbano e a Fertilidade do Solo.................................. 31

4.4. Efeitos da aplicação de CL nas características tecnológicas da cana ............... 37

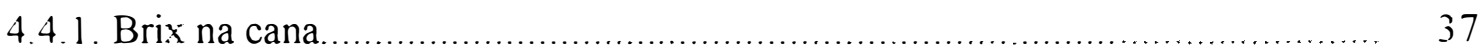

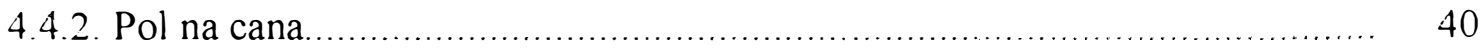




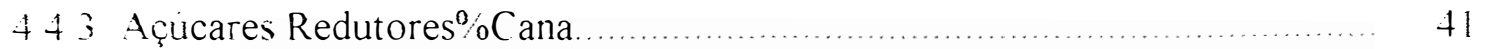

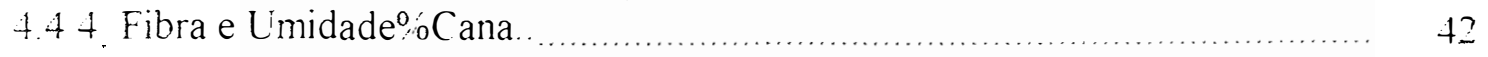

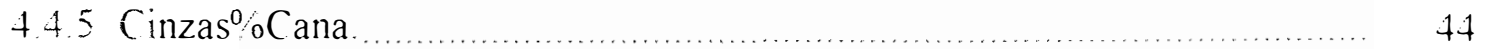

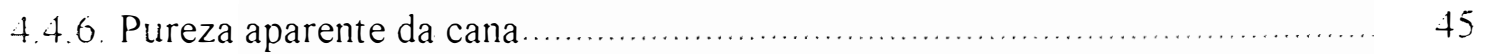

4.47 Açúcar Teórico Recuperảvel ........................................................ 46

45. Efeitos da aplicação de CL no número e peso dos colmos ( $t$ ha-1) e de açúcar

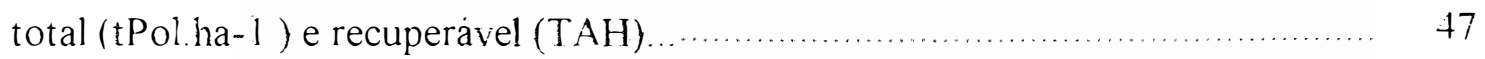

4.6. Efeitos da aplicação de CL nos teores de P ede K no caldo ......................... 54

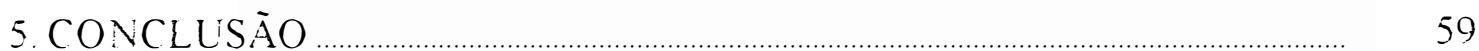

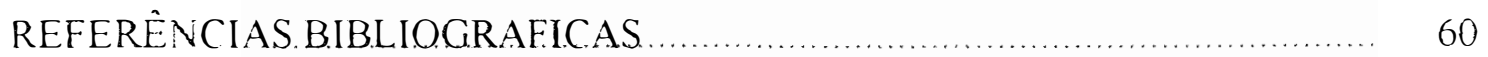




\section{LISTA DE FIGURAS}

Pàgina

Fig̣ura 1. Influència da aplicação de doses de composto de lixo na correção da acidez do solo, medida pela acidez ativa $(a=p H)$, potencial $(b=H+$ $\mathrm{Al})$. soma $(\mathrm{c}=\mathrm{SB})$ e saturação por bases $(\mathrm{d}=\mathrm{V})$ aos 120 dap ............. 34

Fig̣ura 2. Influència da aplicação de doses de composto de lixo na capacidade de troca de cátions $(\mathrm{a}=\mathrm{CTC})$, teores de cálcio $(\mathrm{b}=\mathrm{C} \mathrm{a})$ e de magnésio $(\mathrm{c}=\mathrm{Mg})$ aos $120 \mathrm{dap}$

Fig̣ura 3. Influência da aplicação de doses de composto de lixo nos teores de fósforo $(a=P)$ e de potássio $(b=K)$, com e sem interação com a fonte mineral do elemento $(0, \mathrm{P}, \mathrm{K}, \mathrm{PK})$

Fig̣ura 4. Influència da aplicação de composto de lixo ao solo sobre as caracteristicas tecnológicas da cana-de-açucar ( $a=f i b r a ; b=c i n z a s$ : $c=$ umidade)

Fiğura 5. Influència da aplicação de composto de lixo ao solo sobre a quantidade (a) e produtividade de colmos (b) e nas produções de açucar total (Pol - c) e recuperável (ATR - d) por hectare

Fig̣ura 6. Influência da aplicação de doses de composto de lixo, suplementados 
ou não com $\mathrm{P}$ e/ou $\mathrm{K}$ nos teores de fósforo (a) e de potássio (b) no caldo de cana-de-açúcar. 


\section{LISTA DE TABELAS}

Página

Tabela 1. Composiçào quimica e fisica do composto de lixo urbano

Tabela 2. Teores permissiveis de metais pesados no composto de lixo urbano em alguns paises da Europa e Estados Unidos

Tabela 3. Teores totais máximos de metais pesados considerados admissiveis no solo

Tabela 4. Composiçào química média da torta de filtro (100g de torta úmida)...

Tabela 5. Composiçào média de diferentes tipos de vinhaça ( $\left.\mathrm{Kg} \cdot \mathrm{m}^{-\hat{y}}\right)$

Tabela 6. Análise quimica e física do solo da área experimental.

Tabela 7. Composiçào média do composto de lixo utilizado no experimento.

Tabela 8. Valores médios obtidos para Brix na cana em funçào da adiçào de doses $\left(t^{-h a^{-1}}\right)$ de composto de lixo no decorrer das épocas, em dias após a sua aplicaçào

Tabela 9. Valores médios obtidos para Pol na cana em função das doses de composto de lixo no decorrer das épocas, em dias após a sua aplicaçào. 
Tabela 10. Efeitos da adição combinada de doses de composto de lixo e de suplementação P.K e PK na Pol na cana (média de julho a outubro de 1097)

Tabela 11. Valores médios obtidos para AR \% Cana em função da aplicação de doses (t.ha $\left.{ }^{-1}\right)$ de composto de lixo no decorrer das épocas em dias após a sua aplicaçào

Tabela 12. Valores médios obtidos para Fibra \% Cana em função da adição de doses (t.ha $\left.{ }^{-1}\right)$ de composto de lixo no decorrer das épocas. em dias após a sua aplicação

Tabela 13. Valores médios obtidos para Umidade \% Cana em funçào da adição de doses $\left(\right.$ t.ha $\left.^{-1}\right)$ de composto de lixo no decorrer das épocas, em dias após a sua aplicação

Tabela 14. Valores médios obtidos para Cinzas \% Cana em funçào da adiçào de doses $\left(t_{\text {.ha }}{ }^{-1}\right)$ de composto de lixo no decorrer das épocas, em dias após a sua aplicação

Tabela 15. Valores médios obtidos para Pureza na cana em função da adição de doses de composto de lixo no decorrer das épocas, em dias após a sua aplicação.

Tabela 16. Efeitos da adição combinada de doses de composto de lixo e de suplementação P. K e PK na concentração de Açúcar Teórico Recuperável (ATR) em cana-de-açúcar, expresso em $\mathrm{Kg} / \mathrm{t}$. (média de 4 meses no decorrer de 1997).

Tabela 17. Efeitos da adição combinada de doses de composto de lixo e de 
suplementação $\mathrm{P}, \mathrm{K}$ e PK no número de colmos de cana-de-açuca: por hectare (media de 6 meses finais no decorrer de 1997)

Tabela 18. Efeitos da adição combinada de doses de composto de lixo e de suplementação PK na produtividade de colmos (TCH) de cana-deaçúcar em tha ${ }^{-1}$ na colheita do experimento (meados de outubro/1997)

Tabela 19. Efeitos da adição combinada de doses de composto de lixo e de suplementação $\mathrm{P}, \mathrm{K}$ e $\mathrm{PK}$ na produtividade em açúcar, em toneladas de Pol por hectare

Tabela 20. Efeitos da adição combinada de doses de composto de lixo e de suplementação PK na produtividade de Açúcar Teórico Recuperável por hectare (TAH)

Tabela 21. Teores de fósforo no caldo $\left(\mathrm{mg} \cdot \mathrm{L}^{-1}\right)$ em função das doses de composto de lixo no decorrer das épocas

Tabela 22. Teores de potássio no caldo $\left(\mathrm{mg} \cdot \mathrm{L}^{-1}\right)$ em função das doses de composto de lixo no decorrer das épocas...

Tabela 23. Valor de correlação entre as produtividades da cana-planta, expressa em colmos colhidos aos 369 dap, em relação aos testes de algumas especies químicas do solo, amostrados aos 120 dap. 


\title{
INFLUÊNCIA DA APLICAÇÃO DE COMPOSTO DE LIXO URBANO NA CANA DE AÇÚCAR (Saccharum spp) E NA FERTILIDADE DO SOLO
}

\author{
Autor: Ariovaldo Faustino Soares da Silva \\ Orientador Marco Antonio Azeredo Cesar
}

\section{RESU MO}

Foram estudadas as caracteristicas agrotecnológicas e os teores de $\mathrm{P}$ e $\mathrm{K}$ no caldo de cana-de-açúcar (variedade RB76-5418), como resposta à adubação com composto de lixo urbano aplicado isoladamente ou suplementado com $\mathrm{P}$ e/ou $\mathrm{K}$, acompanhado pelos resultados de fertilidade do solo. O experimento foi conduzido em condições de campo em Piracicaba-SP., utilizando doses de 0, 30, 60 e 90 t.ha $^{-1}$ de composto de lixo (CL) também combinadas com doses de $120 \mathrm{Kg}_{\mathrm{g}}$ ha ${ }^{-1}$ de $\mathrm{P}_{2} \mathrm{O}_{5}$ e $120 \mathrm{Kg} \mathrm{ha}^{-1}$ de $\mathrm{KCl}$. Comparou-se ainda estes tratamentos com a adubação convencional (NPK na formulaçào 4-20-20) na base de 600 $\underline{\text { g h ha }}{ }^{-1}$, segundo recomendações baseadas na análise do solo realizada pela Cooperativa dos Plantadores de Cana de Piracicaba e interpretadas pelo critério do sistema IAC, utilizando a adubaçào fosfatada e potássica, isoladas ou em conjunto, comparadas com a fertilidade original do solo. O delineamento experimental foi o de blocos casualizados com 3 repetições, sendo os tratamentos esiudados em esquema fatorial 4X2X2 (C.L,P,K), totalizando 48 parcelas experimentais. Os dados obtidos permitiram o estabelecimento de relações com os tratamentos e ainda verificações das potencialidades de utilização do composto de lixo urbano como fertilizante na cultura de cana. 
O CL aplicado ao solo neutralizou a acidez potencial totalmente. provocando ainda aumentos no seu $\mathrm{pH}$, na $\mathrm{CTC}$, na soma e na saturação por bases. A adição de $\mathrm{CL}$ elevou linearmente os teores de $\mathrm{P}$ e $\mathrm{K}$ no solo que promoveu aumentos proporcionais de seus teores no caldo. Todavia os teores de $\mathrm{P}$ e $\mathrm{K}$ no caldo foram também influenciados pela adição de fertilizantes fosfatado e potássico. respectivamente.

Não houve atraso na maturação da cana-de-açúcar pela adição de composto de lixo. Entretanto, a resposta ótima da cultura em acumulação de açúcar dos colmos acorreu na combinação do composto com fertilizante ( $\mathrm{P}$ ou K)

A adubaçào na forma de $C L$ proporcionou aumento linear na resposta em produtividade de colmos e açúcar por hectare. 


\title{
INFLUENCE OF THE MUNICIPAL WASTE COMPOST APPLICATION ON SUGAR CANE (Saccharum spp.) AND ON THE SOIL FERTILITY
}

\author{
Author: Ariovaldo Faustino Soares da Silva \\ Adviser: Marco Antonio Azeredo Cesar
}

\section{SUMIARY}

There were studied the agrotecnologycal characteristics and the $\mathrm{P}$ and $\mathrm{K}$ cortents of sugar cane juice (RB76-5418 variety) as response of municipal waste compost (WC) fertilization, applied alone or suplemented with $\mathrm{P}$ and or $\mathrm{K}$, in addition to the soil fertility results. The assay was conducted at field condictions at Piracicaba (Brazil), using 10,60 , and 90t ha ${ }^{-1}$ WC dosages also combined with $120 \mathrm{Kg}_{\mathrm{ga}} \mathrm{h}^{-1}$ of $\mathrm{P}_{2} \mathrm{O}_{5}$ and $120 \mathrm{Kg} \cdot \mathrm{ha}^{-1}$ of $\mathrm{Kcl}$. These treatments were compaired to the conventional fertilization (NPK at 4-20-20 formulation) using 600 $\underline{g} \mathrm{ha}^{-1}$ according to the soil analysis results recommendations of the "Cooperativa dos Plantadores de Cana de Piracicaba" (integrated for IAC system), and also to the $\mathrm{P}$ and $\mathrm{K}$ fertilization, alone or together. and to the soil original fertility. The assay was set up at random blocks with 3 repetitions, beeing studied at the $4 \times 2 \times 2$ (WC, P. K) factorial scheme totalising 48 experiment parcels The results allowed the establishment of relationships between the treatments and also verify the WC potentialities as a sugar cane culture fertilizer.

The WC applied to the soil totaly neutralised the potential acidity rising the $\mathrm{pH}, \mathrm{CTC}$, the bases sum and saturation the WC linearly rised the $\mathrm{P}$ and $\mathrm{K}$ contents of the soil, that promoted proportional increases of their contents in the juice Nevertheless, 
the juice $\mathrm{P}$ and $\mathrm{K}$ contents were also influenced by the phosphated and potassic fertilizers addition. respectively

The WC manuring proportioned linear rise on stalk and sugar productivity responses 


\section{INTRODUÇ̃̃̈O}

Uma das ģrandes preocupaçōes da humanidade é a crescente ģeração de lixo domiciliar, o qual sofre destino inadequado. A compostagem do material orgànico desse lixo minimizará esse efeito, quando utilizado na adubação do solo, melhorará sua fertilidade para a agricultura. Assim sendo, o uso como insumo agricola do composto do lixo sólido domiciliar reduz o custo de fertilizantes. sendo melhor opçào do que depositar em lixōes ou nos chamados aterros sanitários, comuns no Brasil. As vantaggens podem ser mensuradas pelo baixo custo operacional; o uso do produto na fertilizaçào do solo para a ag̣ricultura e a subsequente redução da poluição do ar e da àgua subterrânea, evitando a poluição ambiental reduzindo a carģa orgânica e aumentando sua degradibilidade.

Com a população crescente nas cidades brasileiras, há um aumento nas

geraçòes de residuos denominados de lixo doméstico. A população brasileira é considerada predominantemente urbana, pois a maioria dos habitantes, $75 \%$ do total residem em cidades com mais de 20.000 habitantes.

Devido ao crescente aumento da população brasileira, a maior parte da materia orgànica produzida na agricultura è encaminhada às cidades nas formas de alimentos e materias-primas, que ao serem utilizadas transformam-se em residuos orgânicos que após o descarte irão somar aos residuos inorgânicos descartados

A composição desse lixo urbano varia de acordo com o local de origem, mas de modo geral. contém cerca de 50 a $60 \%$ de material orgânico, o que favorece a sua compostagem

A compostagem do lixo sólido diminui o volume a ser descartado e 
obtendo-se. a partir dele, como produto final, um composto que pode ser utilizado na fertlização do solo . onde proporciona melhorias das caracteristicas físicas, quimicas e biológicas, devido à adição de matéria orgànica e aproveitamento dos nutrientes contidos na fração orgànica do lixo, para nutrir as plantas.

A aceitação e a aplicaçào de compostos de lixo urbano pela sociedade, encontra ainda barreiras e está relacionado com as caracteristicas do composto. Os critérios que determinam a qualidade de um composto variam de acordo com seu uso. Contudo pode-se observar que a baixa aceitaçào se deve a requisitos tais como. aparència fisica incluindo odor e a presença de materiais inertes (pedaços de metais, madeiras, vidros e plásticos); nivel de contaminação com elementos traços, compostos quimicos orgànicos tóxicos e patógenos.

No caso concreto da cana-de-açúcar onde as operações agricolas. na maioria dos casos, sào mecanizadas e, portanto, há uma movimentaçào constante de máquinas e equipamentos, o que causa enormes prejuizos ao solo quanto à sua estrutura. Nesta ótica de idéias pode se considerar que o composto de lixo urbano, quando empregado na agricultura (cana-de-açúcar), redundará numa elevação considerável na produçào e produtividade da cultura, em solos de baixa fertilidade. Além disso, o processo industrial da produção do açúcar e do álcool não devem permitir a passagem do metal pesado, eventualmente contido na planta vinculadoá adição de composto de lixo na lavoura, para o produto final.

Todavia, apesar das vantagens enumeradas do uso agricola do composto é necessário que se defina critérios que regulamente a sua aplicaçào no solo, visando salvaguardar a qualidade ambiental. Pois, pode trazer problemas como a acumulaçào de metais pesados pela adição prolongada do composto de lixo, apesar dos teores originais no resíduo e no solo serem baixos, no caso particular da cana-de-açúcar. 


\section{REVISÃO DE LITERATURA}

\subsection{O lixo urbano}

\subsubsection{Conceito e destino}

A geração de lixo domiciliar atinge patamar abundante e crescente. o qual traz grandes problemas ao meio ambiente e conseqüentes preocupações no intuito de amenizá-los.

O lixo é definido como os resíduos urbanos sólidos e semi-sólidos resultantes de toda e qualquer atividade humana ou animal e que nào tenham valor ou utilidade suficiente para serem conservados (Resende, 1991).

As quantidades geradas diariamente de lixo urbano por habitante variam em funçào do tamanho da cidade. a saber:

a) pequeno e médio porte: estima-se de 400-600g, valores que podem chegar a $1500 \mathrm{~g} / \mathrm{hab} / \mathrm{dia}$;

b) grandes centros urbanos a exemplo de Sào Paulo, em 1995, a produçào diaria de lixo foi da ordem de 12000 t, das quais 9000 t eram de lixo domiciliar.

Entretanto, a compostagem do material orgânico desse lixo virá minimizar aquele efeito, e poderá participar melhorando a fertilidade do solo. Sendo assim, a compostagem do lixo sólido domiciliar é melhor opção do que depositar em lixões ou nos chamados aterros sanitarios As vantagens em comparaçào à deposiçào dos residuos domiciliares a céu aberto podem ser mensuradas pelo baixo custo operacional: o uso do 
produto obtido na agricultura e a subseqüente redução da poluição do ar (mau cheiro), e da contaminação das áğuas superficiais e do lençol freático, não proliferação de insetos e pequenos animais transmissores de doenças, depreciação dos imóveis localizados nas proximidades, foco de doenças para pessoas que atuam como catadores de lixo (Alves, 1996). Todavia, esse material deve ser usado, preferencialmente, após estar decomposto (curtido). A compostagem é uma técnica eficiente para se conseguir a estabilidade da matéria orgânica e a redução de vários patógenos (FAO, 1978) Entretanto. atualmente o destino final do lixo predomina-se ainda a sua disposição em lixōes a céu aberto, 25\% em aterros sanitários, $13 \%$ em aterros controlados, $0,5 \%$ foram incineradas e $1,5 \%$ foram processada em usinas de reciclagem e compostagem (Melo et al.. 1997)

A composição do lixo urbano varia em função do local de origem mas, de um modo geral, contem cerca de $500-600 \mathrm{~g} . \mathrm{kg}^{-1}$ de material orgânico. Essa fração pode ser sensivelmente aumentada com a coleta seletiva do lixo. Procura-se um tratamento integrado do lixo, que envolva a catação de vidro, material ferroso, pilhas, pano, papelão, que serão reciclados, restando o material orgànico, que pode ser compostado ou vermicompostado e entào utilizado como adubo orgânico.

\subsubsection{Compostagem}

Kiehl (1985) define a compostagem como sendo um processo fermentativo microbiológico e controlado de decomposição de materiais orgânicos, transformando-os em um material mais estável e humificado.

A compostagem consiste na oxidação do material orgânico oriundo do lixo por uma sucessão rápida de populações microbianas sob condições aeróbicas, dando origem a um produto estabilizado, de coloração escura, em que os compostos orgânicos sofreram mineralização e processos de neo-síntese, assumindo natureza coloidal denominado composto. Apresenta uma relação $\mathrm{C} / \mathrm{N}$ próxima de 10 e uma composição em elementos minerais que variam em funçào da origem do material que foi compostado e da técnica de compostagem empregada (Melo et al.,1997). 
O processo de compostagem deve incluir uma fase termofilica. cuja temperatura situa-se na faixa de $45-65^{\prime 1} \mathrm{C}$. quando ocorre a higienização do material e uma fase de maturação ou cura, quando ocorre a humificação e a produção do composto propriamente dito (Pereira Neto \& Stentiford, 1992).

O composto pode ser obtido em processos de sistemas abertos, onde a aeração é promovida pelo revolvimento do material em compostagem, ou em processos sofisticados denominados de sistemas fechados, de custos mais elevados, onde o controle da oxigenaação é feita por meio de circulação forçada de ar envolvendo o uso de reatores, que permitem melhor controle da própria aeração, temperatura e umidade. No sistema aberto, o material orgànico é amontoado em leiras com seção triangular, as quais são revolvidas a intervalos de tempo para promover a aeração do meio (Melo et al., 1997).

Xin et al.(1992) citam vários paràmetros operacionais que podem afetar significativamente as propriedades do composto. 1) fonte e natureza da matéria prima a ser compostada; 2) o pré-tratamento; 3) temperatura de compostagem; 4) teor de umidade; 5) grau de aeração; 6) tempo de compostagem.

O lixo deve ser decomposto (parte orgànica) até atingir um material relativamente estável-húmus. Para tanto é necessário ajustar os paràmetros de compostagem, tais como: teor de umidade, aeração e tempo de preparo, os quais proporcionam efeitos significativos na desinfeção do composto, com destruição dos patógenos existentes no lixo e minimizaçào do odor característico (Epstein \& Epstein, 1989)

A velocidade de decomposição do lixo está em função de sua composição, pois os componentes podem ter diferentes graus de facilidades de degradação, tais como: carboidratos e proteinas são de fácil degradação; celulose e gorduras são pouco cegradáveis; e lignina e queratina são de dificeis degradação (Cravo, 1995).

Segundo Cravo (1995) o pré-tratamento do lixo é um fator importante para obter um composto de melhor qualidade e de boa aparência, evitando com que se leve ao campo materiais com alto grau de contaminação do solo, como os fragmentos 
metálicos, que podem principalmente modificar a composiçào quimica do composto Ainda segundo o autor, esse é um processo físico que antecede a compostagem, podendo ser realizado manual ou mecanicamente, havendo uma separaçào de materiais como os plásticos, vidros, metais, papel e papelào.

Na fase de decomposiçào do material orgànico, provenientes do lixo, os microrganismos liberam energia natural de suas atividades biosintéticas, que aquecem o material em decomposiçào e atua favoravelmente para aumentar a intensidade do processo, desde que essa estejam dentro de certos limites (Cravo, 1995)

Temperaturas entre $40-70^{\circ} \mathrm{C}$ indicam a fase de decomposição . temperaturas em queda entre $40-30^{\circ} \mathrm{C}$ correspondem à fase de maturaçào e temperaturas constantes abaixo de $30^{\circ} \mathrm{C}$ indicam o final do processo. Temperaturas acima de $75^{\circ} \mathrm{C}$ sào condições inadequadas do processo de compostagem pois, o processo passa a ser controlado por reações químicas, exalando odores desagradáveis (Grossi, 1993).

A mineralizaçào dos componentes orgànicos ocorre na fase da decomposiçào quando a temperatura situa-se na faixa de 55 a $60^{\circ} \mathrm{C}$. Elimina-se também microrganismos patogênicos, insetos, larvas e sementes de ervas daninhas (Pereira Neto, 1997).

Umidade superior a 70\% pode causar a deterioraçào dos materiais e inferior a 35\% pode afetar a atividade microbiológica (Kiehl, 1985).

De acordo com Grossi (1993), para que haja melhor desempenho das atividades dos microrganismos, em se tratando das transferências dos nutrientes e produtos metabólicos para o meio onde estào, a umidade deve ser mantida na faixa de $45-70 \%$.

Na compostagem do lixo urbano o sistema prevalecedor é o aeróbico (Pereira Neto, 1992).

O elemento oxidante no processo de decomposiçào aeróbica é o oxigènio do próprio ar, sendo fundamental a aeraçào dos resíduos orgànicos quando estes estào sendo compostados, criando condições favoráveis para o crescimento e metabolismo dos 
microrganismos. Além da aeração manter a temperatura em condiçōes favoráveis há decomposiçào do material orgânico (Egreja Filho, 1993)

O periodo de maturaçào do composto é variável depende do material usado para a compostagem, podendo maturar em um espaço de tempo entre dois a seis meses (Cravo, 1995).

Salienta-se que o composto pode ser produzido de maneira bem simples, em processos denominados de sistemas abertos, onde a aeraçào é promovida pelo revolvimento do material em compostagem, ou em processos mais sofisticados, denominados de sistemas fechados, em que o controle da oxigenação é feita por meio de circulaçào forçada de ar. No sistema aberto, o material orgânico é amontoado em leiras com seçào triangular, as quais sào revolvidas a intervalos de tempo para promover a aeraçào do meio. O sistema fechado envolve o uso de reatores, que permitem melhor controle das condiçòes de aeração, temperatura e umidade, mas, evidentemente, apresenta custos mais elevados (Melo et al., 1997).

Xin et al. (1992) define a maturaçào do composto como sendo o grau de estabilidade nas propriedades fisicas, quimicas, e biológicas. De acordo com Zuconni et al. ( 1981 ) no final da compostagem, obtém-se um composto maduro de fácil manuseio e contribui com decisào para a melhoria da estrutura e da fertilidade do solo. quando empregado na agricultura

DeVleeschauwer et al. (1981), observaram que no composto imaturo haviam presenças de ácidos orģânicos (acético, propiônico, isobutírico e isovalérico). Enquanto que em compostos maturados encontraram apenas pequena quantidade de ácido acético Ainda os autores verificaram que a presença de ácido acético inibiu a emergência de sementes Lepidium sativum L. quando esta dose ultrapassa o valor de 300 ppm

O composto de lixo urbano ainda nào possui boa aceitabilidade pela sociedade, devido as caracteristicas do composto (Cravo, 1995)

No Brasil, o fator que conduz a produçào de compostos de baixa qualidade se relaciona principalmente à presença de poluentes orgânicos e inorgânicos, e 
a melhoria deste produto seria pela prática da coleta seletiva do lixo domiciliar. onde a obtenção do material não colocasse o meio ambiente em risco através de contaminações (Grossi, 1993; Egreja Filho, 1993).

Os critérios que determinam a quantidade de um composto variam de acordo com o uso. Os seguintes requisitos podem ser observados: a) aparência fisica, incluindo odor e a presença de materiais inertes, como: pedaços de metais, madeira, vidros e plásticos (Richard, 1990); b) nivel de contaminação com elementos-traço, compostos químicos orgânicos tóxicos e patógenos (Epstein \& Epstein, 1989; Richard, 1990; Walker \& Odonnel, 1991); c) valor fertilizante e condicionador do solo (Airan \& Ebell, 1980; De Haan, 1981).

Os compostos de lixo urbano possuem variações químicas amplas, devido as diferentes regiōes geográficas, variação sazonal, diversidades de matérias primas e de usinas de compostagem com diferentes sistemas, tanto nas etapas de pré-tratamento como no controle do processamento (Xin et al., 1992). Esses autores, compararam dados analíticos de compostos de lixo dos Estados Únidos e da Europa e constataram uma variação tanto nos teores dos macro como dos micro elementos determinados ,os teores de umidade também variaram de 20-50\%, com uma matéria seca mantendo-se numa faixa de $50 \%$ com pouca variação. O pH das amostras analisadas mostraram-se neutros ou ligeiramente alcalinos

Com relação aos teores de macronutrientes, o composto de lixo apresenta o $\mathrm{N}$ em quantidades relevantes (Berton \& Valadares, 1991). Mas somente de 10 a $15 \%$ do $\mathrm{N}$ total do composto torna-se disponivel no primeiro ano de cultivo (De Haan, 1981 ).

U'ma aplicação de 30 tha $^{-1}$ de um composto de lixo com $40 \%$ de umidade, segundo (Berton \& Valadares, 1991), adicionaria ao solo cerca de $200 \mathrm{~kg}$ de N, $36 \mathrm{~kg}$ de $\mathrm{P}\left(82 \mathrm{~kg}\right.$ de $\left.\mathrm{P}_{2} \mathrm{O}_{5}\right), 56 \mathrm{~kg}$ de $\mathrm{K}\left(67 \mathrm{~kg}\right.$ de $\left.\mathrm{K}_{2} \mathrm{O}\right)$ e $54 \mathrm{~kg}$ de $\mathrm{S}$.

Os teores de $\mathrm{P}$ nos compostos de lixo urbano são consideravelmente mais altos do que aqueles da maioria dos solos agricolas, mas, sua disponibilidade para as plantas é baixa (Cravo, 1995). De acordo com De Haan, (1981), tanto no primeiro como no segundo ano de cultivo o $\mathrm{P}$ ficou disponivel do seu total, em $15 \%$. 
O composto de lixo urbano é rico em $\mathrm{K}$ e Na principalmente (Melo, et al., 1997) Segundo De Haan (1981), os teores de K sào mais baixos do que a maioria dos solos agrícolas, mas sua disponibilidade é alta como o de muitos fertilizantes

Com referência aos micronutrientes, geralmente apenas $\mathrm{Zn}$, Fe e $\mathrm{Cu}$ apresentam-se com alguma expressào. Uma dosagem de 30 tha $^{-1}$ de composto forneceria cerca de $5 \mathrm{~kg}$ de Zinco (Raij et al., 1985)

A composição química e física do composto de lixo (Berton \& Valadares, 1991 ) é apresentada na Tabela 1.

Tabela 1. Composiçào química e física do composto de lixo urbano

\begin{tabular}{ll}
\hline Componentes & Quantidade \\
\hline $\mathrm{MO}$ & $190-530 \mathrm{~g} \cdot \mathrm{Kg}^{-1}$ \\
$\mathrm{pH}$ água & $6,8-8,3$ \\
$\mathrm{C} / \mathrm{N}$ & $8,0-16,1$ \\
Umidade & $40 \mathrm{~g} \cdot \mathrm{Kg}{ }^{-1}$ \\
$\mathrm{~N}$ & $1,0-1,5 \mathrm{~g} \cdot \mathrm{Kg}^{-1}$ \\
$\mathrm{P}$ & $0,2-0,53 \mathrm{~g} \cdot \mathrm{Kg}^{-1}$ \\
$\mathrm{~K}$ & $0,3-0,6 \mathrm{~g} \cdot \mathrm{Kg}^{-1}$ \\
$\mathrm{Ca}$ & $2,1-5,4 \mathrm{~g} \cdot \mathrm{Kg}^{-1}$ \\
$\mathrm{Mg}$ & $0,3-0,5 \mathrm{~g} \cdot \mathrm{Kg}^{-1}$ \\
$\mathrm{~S}$ & $0,2-0,3 \mathrm{~g} \cdot \mathrm{Kg}^{-1}$ \\
$\mathrm{Cu}$ & $162 \mathrm{mg} / \mathrm{dcm}$ \\
$\mathrm{Zn}$ & $262 \mathrm{mg} / \mathrm{dcm}$ \\
\hline $\mathrm{Fe}$ & $1: 600 \mathrm{mg} / \mathrm{dcm}^{3}$ \\
\hline $\mathrm{Fonte}$ &
\end{tabular}

Fonte. adaptada de Berton \& Valadares (1991)

Já a legislação brasileira considera o composto como um fertilizante composto, mas, nào faz mençào sobre o teor de metais pesados permissíveis, como ocorre em alguns paises da Europa e nos Estados Unidos (Tabela 2). 
Tabela 2. Teores permissiveis de metais pesados no composto de lixo urbano em alguns paises da Europa e Estados Unidos.

\begin{tabular}{|c|c|c|c|c|c|c|c|}
\hline \multirow[t]{2}{*}{ País } & \multicolumn{7}{|c|}{ Elementos $\left(\mathrm{mg} . \mathrm{Kg}^{-1}\right)$} \\
\hline & $\mathrm{Pb}$ & $\mathrm{Cu}$ & $\mathrm{Zn}$ & $\mathrm{Cr}$ & $\mathrm{Ni}$ & $\mathrm{Cd}$ & $\mathrm{Hg}$ \\
\hline Alemanha & 150 & 100 & 400 & 100 & 50 & 1,5 & 1 \\
\hline Minnesota (USA) & 500 & 500 & 1000 & 1000 & 100 & 10 & 5 \\
\hline França & 800 & & & & 200 & 8 & 8 \\
\hline Áustria & 900 & 1000 & 1500 & 300 & 200 & 6 & 4 \\
\hline Itália & 500 & 600 & 2500 & 500 & 200 & 10 & 10 \\
\hline Suiça & 150 & 150 & 500 & & & 3 & 3 \\
\hline Holanda & 20 & 300 & 900 & 200 & 50 & 2 & 2 \\
\hline
\end{tabular}

Fonte: adaptada de Grossi (1993).

\subsection{Uso agricola do composto}

Quase toda a parte orgânica do lixo é reaproveitável quando este é compostado. É uma forma de reciclagem, onde este processo diminui o volume do lixo e o seu produto final pode ser usado na fertilização do solo, sendo possível, o reaproveitamento dos nutrientes contidos na fração orgânica do lixo (Cravo, 1995). Além da riqueza em matéria orgânica e nutrientes para as plantas, deve ser salientado a ausência de microrganismos patogênicos, estas características são importantes, o que o torna recomendável para uso agricola (Melo et al., 1997).

Messias \& Morais (1992) realizaram pesquisa com "milheto", (Pennisetum americamum) empregando composto de lixo urbano da cidade de OlindaPE, com 70 dias de compostagem. Utilizou-se de casa de vegetação e solo LVA, e doses crescentes de composto (10,20,30 e 40 t.ha" $\left.{ }^{-12}\right)$, com, e sem suplementação de $N$ $\left(80 \mathrm{~kg} . \mathrm{ha}^{1}\right)$ na forma de bicarbonato de amônio e verificaram que a dose de 20 e $30 \mathrm{t}$. ha ${ }^{-1}$ propiciou uma maior produtividade. 
Moraes \& Selbach (1991) conduzindo experimento em campo, em solo Podzolítico Vermelho Escuro avaliaram o efeito do composto de lixo urbano sobre a produção da aveia (Avena Strigosa) e milho (Zea mays), mediante duas aplicações sucessivas nas doses de 20,40,80 e 160t. ha ${ }^{-1}$ antes de cada cultura. Observaram uma resposta significativa do rendimento das culturas às adições de composto, sendo que os tratamentos com doses a partir de 80 tha $^{-1}$ resultaram num rendimento de milho igual ou superior ao que obtido com fertilizante mineral. Houve um significativo aumento no $\mathrm{pH}$ do solo em todas as doses aplicadas do composto. A dose mais alta elevou o pH para 6,7. Os teores de N, P, K, Ca, Mg, C orgânico e a CTC do solo após a última cultura foram maiores do que os teores iniciais, com as doses a partir de 40t.ha ${ }^{-1}$. Também as quantidades de fungos e bacterias, tendeu a aumentar com as maiores doses de composto.

Santos \& Stamford (1991) estudaram em casa de vegetação, os efeitos de doses de fósforo na forma de fosfogesso, com e sem composto de lixo urbano do municipio de Igarassú-PE, no rendimento da leucena e nas características químicas de uma LVA distrófico. O fosfogesso foi aplicado ao solo nas doses equivalente a 0,40 e $80 \mathrm{ppm}$ de P. Foi adicionada uma testemunha comparativa com $80 \mathrm{ppm}$ na forma de superfosfato triplo, sem composto de lixo. A adição de composto de lixo ao solo favoreceu o rendimento da leucena, aumentando o peso dos nódulos em $60 \%$; e elevou o $\mathrm{pH}$ e a disponibilidade de $\mathrm{P}$ no solo; reduziu a concentração de $\mathrm{AL}$ e não modificou significativamente os teores de $\mathrm{Ca}+\mathrm{Mg}$ trocável do solo. Na presença de composto urbano, a disponibilidade de fósforo tendeu a diminuir com o aumento das doses de gesso.

Collier et al. (1992), testaram as doses de 0, 20 e 40t ha ${ }^{-1}$ de composto de lixo urbano da cidade do Rio de Janeiro, 3 fontes de Ca e Mg (calcário dolomítico, gesso agricola e testemunha) e dois niveis de adubação mineral NPK (O e 70kg na formulação 10-5-15). Os objetivos foram avaliar as alterações nos principais indicadores de fertilidade do solo e nos resultados de produção das hortaliças (berinjela e milho doce) cultivados em sucessão. O composto foi capaz de elevar os niveis de Ca e Mg no solo, superando as fontes de minerais; as doses de matéria orgânica proporcionaram elevação 
significativa no $\mathrm{pH}$, neutralizaram o teor de $\mathrm{AL}$ e reduziram a acidez potencial $(\mathrm{AL}+\mathrm{H})$ do solo; o K trocável apresentou elevação significativa com as doses de composto, o P assimilável $\left(\mathrm{P}_{2} \mathrm{O}_{5}\right)$ já se encontrava elevado e não ocorreu elevação significativa. A produção de $\mathrm{Ca}$ e $\mathrm{Mg}$ e o milho doce apresentou boas produtividades, porém sem significância estatistica.

Parra et al.(1997), com o objetivo de avaliar agronomicamente o composto de lixo urbano estudaram doses de 0 a 40 tha $^{-1}$, em um LRd. Encontraram significativa redução nos teores de $\mathrm{H}^{-}+\mathrm{AL}^{3^{+}}$, aumentos de $\mathrm{pH}$ e nos teores de $\mathrm{P}$ (Mehlich 1), o que elevou em $102 \%$ com a maior dose. Os incrementos nos rendimentos de algodão, em geral, foram baixos e variaram de $5-11 \%$ em quatro safras, das quais foram significativas somente em duas. Considerando-se os rendimentos acumulados nas sucessivas safras verificaram que estes cresceram com as doses estudadas.

Santana Filho et al. (1997), desenvolveram um trabalho com o objetivo de colonizar vegetalmente o horizonte $\mathrm{C}$ de um solo empregando sementes de gramineas e leguminosas, em tratamentos com e sem composto de lixo. Obtiveram como resultado o rápido recobrimento da área e boa produção de matéria seca pelas plantas concluindo que a utilização do composto pode ser uma alternativa para recuperação de áreas degradadas.

Mazur et al. (1983), estudaram o efeito do composto de lixo urbano na disponibilidade de fósforo em solo ácido, empregando-se doses de $150 \mathrm{~kg}^{\text {. ha }}{ }^{-1}$ de $\mathrm{P}$ (superfosfato triplo), de 150 e $450 \mathrm{~kg}^{-h^{-1}}$ (Fosfato de Araxá). Os tratamentos foram testados na presença e ausência de composto de lixo urbano na dose de 30 tha $^{-1}$. Todos os tratamentos foram testados na presença de $\mathrm{N}$ e calagem. O experimento foi conduzido em casa de vegetação, empregando-se milho (Zea mays) como planta teste. Como resultado obtiveram somente a mineralização do composto que ocasionou elevação nos niveis de $\mathrm{P}$ assimilável e ainda nos tratamentos que receberam composto a média dos valores do $\mathrm{pH}$ elevou-se 5,2 para 5,7 com decréscimo médio do alumínio trocável de $0.55 \mathrm{meq} / 100 \mathrm{~cm}^{3}$

Em sintese a aplicação de composto ao solo promove elevação do $\mathrm{pH}$ (Messias \& Moraes, 1992; Hernando et al., 1989). Em solos ácidos e com elevados 
teores em Al, além de elevar o $\mathrm{pH}$, o composto forma complexos estáveis com o metal, diminuindo sua disponibilidade para as plantas (Igue \& Pavan, 1984).

Santos \& Stamford (1993), observaram o efeito do composto urbano da Prefeitura de Recife, suplementado com fósforo, na correção e acidez do solo PVAL de textura média, em casa de vegetação, com doses de $0,80,160$ e $240 \mathrm{~g} \cdot \mathrm{kg}^{-1}$ (superfosfato triplo). Cultivaram caupi como planta teste. Esses autores concluíram que o composto foi eficiente como corretivo do solo e também influenciou na disponibilidade de $\mathrm{Ca}, \mathrm{Mg}$ e $\mathrm{P}$. No nivel $80 \mathrm{~g} . \mathrm{kg}^{-1}$ de composto aumentou o $\mathrm{pH}$ de 4,8 para 6,7 neutralizando todo o alumínio trocável. As aplicações de 80,160 e $240 \mathrm{mg}^{\mathrm{kg}} \mathrm{kg}^{-1}$ de composto orgânico, proporcionaram aumentos de 100, 170 e 200\% na disponibilidade de $\mathrm{Ca}+\mathrm{Mg}$, respectivamente. O P teve disponibilidade maior pela interação do composto + fósforo suplementar com acréscimos proporcionais aos níveis de composto. O nível de composto $160 \mathrm{~g} \cdot \mathrm{kg}^{-1}$ suplementado com 30mg. $\mathrm{kg}^{-1}$ de P, proporcionou o maior aumento na disponibilidade de fósforo elevando o teor de $2,4 \mathrm{mgkg}^{-1}$ para $120 \mathrm{mg} \mathrm{kg}^{-1}$.

Santos et al. (1994),com o objetivo de estudarem a influência do composto urbano, em casa de vegetação no desenvolvimento da Leucena inoculada com Rhizobium loti e com micorriza arbusculares ( MVAf), com incorporação do composto no nivel $(5 \%)$ na base de volume, e aplicação crescente de fósforo nas doses de 0, 40 e $80 \mathrm{mg} \cdot \mathrm{kg}^{-1}$ (super fosfato triplo) num Latossolo Vermelho Amarelo distrófico. Com a incorporação do composto orgânico quando inoculado com as micorrizas, propiciou um aumento de $57 \%$ na acumulação de $\mathrm{N}$ total na parte aérea da planta, e a adubação fosfatada favoreceu esta variável apenas na dose $80 \mathrm{mg} \cdot \mathrm{kg}^{-1}$. O composto propiciou interações com a adubação fosfatada e, com as MVAf aumentou a absorção dos fósforo pela parte aérea das plantas em mais de $100 \%$. A interação composto e fósforo aumentou a absorção em todas as doses usadas. A adição de 15 t.ha ${ }^{-1}$ de composto na presença da inoculação com Rhizobium loti, promoveu um aumento de $100 \%$ na produção de matéria seca da parte aérea das plantas. A adição de composto urbano, concluíram os autores, além de favorecer a nodulação (aumento em peso de 60\%), a atividade da nitrogenase e o acúmulo do nitrogênio e do fósforo interagiu positivamente com o Rhizobium loti e com 
o fungo MVAf, aumentando a absorção de N-total a de fösoro e beneficiou a fixação simbiótica de $\mathrm{N}_{2}$.

Quanto as propriedades fisicas modificadas pela adição de composto de lixo, Hernando et al. (1989), observaram que ao aplicarem $60 \mathrm{t} \cdot \mathrm{ha}^{-1}$ de composto a um solo arenoso, após um periodo de 90 dias de incubação, houve aumento na porcentagem de agregados e na capacidade de retenção de água

Já no tocante a metais pesados, diversos autores observaram efeitos da adição de composto de lixo : na alface e ervilha aumentos na absorção de $\mathrm{Cu}$ e $\mathrm{Zn}$ (Purves \& Mackenzie, 1973) sem prejuizos para produção e fitotoxidez ao Zn na alface (Hernandez, 1992). Em termos de acumulação de metal pesado em olericolas seria o $\mathrm{Pb}$ que concentraria-se no tecido foliar de acordo com Boon \& Solstanpour (1992). Na cultura do milho, doses de composto de lixo de 30tha ${ }^{-1}$ durante 4 anos determinaram aumento no teor de $\mathrm{Zn}$ e $\mathrm{Cd}$ nas raizes, de $\mathrm{Cu}$ e $\mathrm{Zn}$ nos grãos, de $\mathrm{Ni}$ nas raizes no quarto ano; os teores de $\mathrm{Pb}$ e $\mathrm{Cr}$ nos grãos não foram afetados (Petruzzelli, 1989). A EPA (1983) já estabeleceu os teores de metais pesados considerados como permissiveis nos solos (Tabela 3).

Tabela 3. Teores totais máximos de metais pesados considerados admissiveis no solo.

\begin{tabular}{ll}
\hline Elementos & Concentração $\left(\mathrm{mg} \cdot \mathrm{kg}^{-1}\right)$ \\
\hline $\mathrm{Mn}$ & $500-900$ \\
$\mathrm{Zn}$ & 50 \\
$\mathrm{Cu}$ & 100 \\
$\mathrm{Cd}$ & 1 \\
$\mathrm{Ni}$ & 40 \\
$\mathrm{Cr}$ & 100 \\
$\mathrm{~Pb}$ & 25 \\
\hline
\end{tabular}

Fonte: EPA (1983) 


\subsection{Potencialidade de Uso de Materiais Orgânicos (Composto de Lixo) na Cultura de Cana-de-Açúcar}

\subsubsection{Efeitos benéficos da adição de matéria orgânica ao solos e resposta da cultura de cana-de-açúcar à aplicação de fontes orgânicas de nutrientes.}

A matéria orgânica do solo é de origem vegetal e animal. Seus componentes orgânicos são representados nos mais variados estados de decomposição (Kiehl, 1968).

O húmus é um componente do solo bastante transitório e deve ser renovado constantemente (Brady, 1968). Todavia, a reposição do húmus e estabilização no solo é dificultado no caso do cultivo de cana-de-açúcar, onde as operações agricolas na maioria dos casos são mecanizadas. Portanto, há uma movimentação constante de máquinas e equipamentos, o que causaria enormes prejuizos ao solo quanto a sua estrutura, se medidas pertinentes não forem acionadas. Nesta ótica de idéias, pode-se afirmar que o composto de lixo urbano pode fornecer além de nutrientes a cultura da cana, também propiciará melhora nas propriedades fisicas e biológicas dos solos. O que redundará numa elevação considerável na produção e produtividade da cana-de-açúcar, em solos de baixa fertilidade. Lembrando que não há solo fértil sem matéria orgânica, de modo que a produtividade de uma determinada cultura diminui quando se reduz o teor de húmus existente no solo (Gomes, 1950).

Kiehl (1968), afirma que a matéria orgânica dos solos se apresenta acumulada nos horizontes superficiais e mesmo assim o conteúdo deste material é reduzido.

Azeredo \& Manhães (1983), citando diversos autores apontam os principais beneficios que matéria orgânica traz às propriedades do solo, sendo considerada como importante fator na produtividade agricola:

a) Aumento da disponibilidade de nitrogênio, fósforo e enxofre, através do processo de mineralização da matéria orgânica; 
b) Elevação da capacidade de troca de cátions;

c) Diminuição da fixação de fósforo por oxidos amorfos, pois, os radicais orgânicos bloqueiam os sitios de fixação;

d) Aumenta a agregação, reduzindo a suscetibilidade á erosão;

e) Aumenta a capacidade de retenção de água;

f) Favorece a atividade microbiana

Deve ser ressaltado que o teor de carbono orgânico nos compostos (com base no peso seco) está em torno de $30 \%$, valor considerado alto. O teor da matéria orgânica faz com que os compostos sejam excelentes condicionadores de solos, principalmente os pobres em matéria orgânica. Já os teores de $\mathrm{N}$ e $\mathrm{P}$ nos compostos de lixo urbano são relativamente superiores aos encontrados na maioria dos solos agricolas, contudo suas disponibilidade para as plantas são baixas, uma vez que de acordo com De Haan (1981), somente 10 a $15 \%$ do $\mathrm{N}$ total do composto torna-se disponivel no primeiro ano de cultivo, não existindo efeito residual no segundo ano. Em relação ao fósforo, ate $15 \%$ do $\mathrm{P}$ contido no composto fica disponivel no primeiro e segundo ano respectivamente. $\mathrm{O}$ composto de lixo é também uma importante fonte de $\mathrm{K}$ para as plantas.

Deve ser lembrado também que a adição de fontes orgânicas de nutrientes na cultura de cana-de-açúcar é comum, sendo os mais usuais a torta de filtro e a vinhaça. A vinhaça é um adequada fonte de K para a cultura de cana-de-açúcar, enquanto a torta de filtro fornece principalmente P e Ca para o solo (Cesar \& Silva, 1993).

\subsubsection{Efeito de matéria orgânica e do potássio na qualidade tecnológica da cana-de- açúcar: riscos à maturação pela adição de composto de lixo.}

A qualidade da cana-de-açúcar depende de uma série de fatores tais como, a variedade, condições climáticas, ciclo da cultura e do estado nutricional da planta (Korndorfer \& Martins, 1992).

$\mathrm{Na}$ cultura da cana-de-açúcar é de prática comum o emprego da adubação orgânica com o aproveitamento dos resíduos orgânicos gerados na própria indústria 
sucro-alcooleira, como a torta de filtro rotativo e a vinhaça (Marques \& Marques, 1987; CNE, 1987), o que afeta em sobremaneira à fertilidade natural e a disponibilidade hidrica no solo. A melhoria e a manutenção da fertilidade do solo pela adição de residuos orgânicos promove a maior sustentabilidade do sistema de produção de cana-de-açúcar.

Pois, o crescimento e modernização do setor agricola canavieiro trouxe problemas de esgotamento das reservas orgânicas naturais do solo. Os residuos orgânicos, urbanos e agroindustriais são mais abundantes, baratos e podem repor à fertilidade do solo (Polo et al., 1988).

A produção média de torta de filtro está na faixa de $18-30 \mathrm{Kg}^{-1} \mathrm{t}^{-1}$ de cana moida (Demattê, 1992).

Este residuo é material rico em matéria orgânica, cálcio, fósforo e nitrogênio, porém carente em potássio e magnésio (Glória et al, 1974). E entre os micronutrientes o ferro, cobre, zinco e manganês aparecem com destaque.

Gloria et al. (1974) coletou 22 amostras de torta de filtro da Usina da Pedra (Serrana-SP) durante o transcorrer da safra e obteve a composição quimica média na Tabela 4.

Tabela 4. Composição quimica média da torta de filtro (100g de torta úmida)

\begin{tabular}{|c|c|c|c|c|c|c|c|}
\hline \multirow[t]{2}{*}{ Macronutrientes: } & $\begin{array}{l}\mathrm{C} \\
(\mathrm{g})\end{array}$ & $\begin{array}{l}\mathrm{Ca} \\
(\mathrm{g})\end{array}$ & $\begin{array}{l}\mathrm{Mg} \\
(\mathrm{mg})\end{array}$ & $\begin{array}{l}\mathrm{K} \\
(\mathrm{mg})\end{array}$ & $\begin{array}{l}\mathrm{N} \\
(\mathrm{g})\end{array}$ & $\begin{array}{l}\mathrm{SO}_{4} \\
(\mathrm{~g})\end{array}$ & $\begin{array}{l}\text { P Total } \\
(\mathrm{mg} / \operatorname{lo0g~ms})\end{array}$ \\
\hline & 8,04 & 0,80 & 76,90 & 56,64 & 0,28 & 0,79 & 7,66 \\
\hline \multirow[t]{2}{*}{ Micronutrientes: } & $\begin{array}{l}\mathrm{Cu} \\
(\mathrm{ppm})\end{array}$ & $\begin{array}{l}\mathrm{Mn} \\
(\mathrm{ppm})\end{array}$ & $\begin{array}{l}\mathrm{Zn} \\
(\mathrm{ppm})\end{array}$ & $\begin{array}{l}\text { Mo } \\
\text { (ppm) }\end{array}$ & $\begin{array}{l}\text { Co } \\
\text { (ppm) }\end{array}$ & $\begin{array}{l}\mathrm{Fe} \\
(\%)\end{array}$ & \\
\hline & 65,0 & 623,9 & 88,7 & 0,64 & 1,4 & 2,51 & \\
\hline Mat. Orgânica & $\begin{array}{l}75,95 \\
\%\end{array}$ & & & & & & \\
\hline
\end{tabular}

Fonte: Gloria et al. (1974)

*ms = matéria seca 
Quando se aplica torta de filtro no sulco de plantio da cana-de-açúcar existe efeito positivo no aumento de produtividade (Albuquerque \& Marinho, 1979; Coleti et al.,1979). A torta de filtro pode ser usada como substituto do fósforo mineral principalmente em solo de menor fertilidade (Coleti et al., 1981; Prasad, 1974).

Em solos de baixa fertilidade, existem respostas positivas à adubação fosfatada quando associada à torta de filtro (Coleti et al.,1980).

Quanto ao nitrogênio, Albuquerque \& Marinho (1979) observaram que a torta pode substituir parcialmente este elemento quando empregaram uma quantidade de $4 \mathrm{t}$. ha ${ }^{-1}$ do adubo orgânico em base seca

A complementação mineral de potássio quando se usa a torta de filtro resulta em efeitos positivos, principalmente em solos com baixo teor deste elemento (Coleti et al., 1981). Em solos com teores médio a alto em potássio não é necessário a complementação mineral (Prasad, 1974)

Tortas de filtro com relação $\mathrm{C} / \mathrm{N}$ na faixa de 17 permite uma rápida mineralização do nitrogênio e acima de 33 ocorre imobilização, não deixando-o disponivel para a cultura havendo a necessidade de complementação (Beauclair, 1984).

Castro \& Godoy (1979), Indicaram que 3 t.ha $^{-1}$ de torta de filtro seca adicionada de adubação mineral (NPK), aplicadas no sulco de plantio da cana-de-açúcar, foram suficientes para aumentar a eficiência da adubação mineral e elevar a produtividade em $14 \mathrm{t} \cdot \mathrm{ha}^{-1}$ de cana e $2,8 \mathrm{t} \cdot \mathrm{ha}^{-1}$ na produção da pol, quando comparadas com o tratamento que recebeu apenas NPK

Marinho et al. (1976) obtiveram acréscimos de até $24 \mathrm{t} \cdot \mathrm{ha}^{-1}$ de cana com a aplicação de $4 \mathrm{t} \cdot \mathrm{ha}^{-1}$ de torta de filtro seca, em solo arenoso e influenciou positivamente a adubação nitrogenada. Ainda esse autores demonstraram que a aplicação de $24 \mathrm{t}$. ha ${ }^{-1}$ de torta de filtro fresca no sulco de plantio, juntamente com a adubação mineral, causou aumentos de até $56 \mathrm{t} \mathrm{ha}^{-1}$ de peso em cana em comparação com o tratamento que recebeu apenas a adubação mineral

Já Simões Neto et al.(1987) em experimentação com torta de filtro aplicada no sulco de plantio da cana-de-açúcar na dosagens de 20 e 30t.ha ${ }^{-1}$, 
comparando-se com a adubação mineral (NPK) num solo de textura arenosa/média, concluiram que não houve diferença estatística significativa, mas a medida que aumentou a dosagem ocorreu uma tendência de um maior aumento na produtividade.

Mattiazzo \& Gloria (1987), avaliaram em condições de laboratório a torta de filtro como fertilizante fosfatado e concluiram que as tortas quando úmidas têm uma capacidade de fornecimento de fósforo equivalente aos superfosfatos simples e triplo quando aplicadas em Areias Quartzosa, mas se aplicadas em Latossol Roxo essa capacidade se revela inferior aos superfosfatos. As tortas de filtros quando secas possuem baixa capacidade de fornecimento de fósforo.

A composição do caldo da cana-de-açúcar é importante para o processo industrial, principalmente, na relação entre teor de fósforo no caldo e capacidade de clarificação. Para a obtenção do açúcar e do álcool, Coleti et al.(1992), concluíram que a adição de torta de filtro no sulco de plantio da cana-de-açúcar, na dosagem de 20t.ha ${ }^{-1}$, adicional à adubação básica (NPK) como fonte de matéria orgânica ou aplicada solitariamente como única fonte de fósforo, influenciou positivamente nos teores de $\mathrm{P}_{2} \mathrm{O}_{5}$ no caldo, apresentando teores na faixa de 200 a 300 ppm, como menciona Silva Jr. (1975) sendo este teor satisfatório para que haja uma boa clarificação.

Coleti et al. (1982), mostraram que aplicando-se doses próximas a 20t.ha-1 de torta úmida no sulco é possivel substituir totalmente a adubação mineral potássica.

Analisando a questão do efeito sobre perfilhamento da cana, Alleoni et al. (1995) encontraram respostas significativas à aplicação de torta de filtro, no sulco de plantio, da variedade RB73-5275, em um podzólico vermelho-amarelo, com dose de 15 t.ha ${ }^{-1}$ de matéria seca, em comparação com a adubação mineral, obtendo-se resultados de aumentos de $53 \%$ no perfilhamento e $86 \%$ para a altura de colmos. O peso de colmos foi maior para o tratamento com a torta de filtro.

Nunes Jr. \& Casagrande (1986), realizaram estudos comparativos com 20 variedades de cana-de-açúcar na presença de torta de filtro na dose de 20 tha $^{-1}$, e verificaram que estas apresentaram ganhos médios da ordem de $19,6 \mathrm{t}^{\mathrm{h}} \mathrm{h}^{-1}$ de peso de colmos e 2,1 t.ha ${ }^{-1}$ de açúcar, em três cortes realizados. Também avaliaram que a torta de 
filtro levou a cultura a uma maior vegetação, conduzindo a uma retardamento médio de aproximadamente trinta dias na maturação das variedades no periodo inicial de safra. Outro experimento foi realizado por Nunes Jr. et al. (1988) confirmou-se os resultados anteriores com novos clones de cana-de-açúcar, nas mesmas condições experimentais, empregando 35 tha $^{-1}$ da torta no sulco de plantio em solo vermelho escuro distrófico. Compararam-as com a adubação básica (NPK). Os autores concluiram que o efeito da torta de filtro proporcionou um ganho médio de $13,4 \%$ tanto em peso de colmos como o de açúcar por hectare, e quanto à maturação não houve prejuizos para as variedades empregadas, mesmo que tenham sido levadas a uma maior vegetação devido ao emprego da torta de filtro.

Já a vinhaça, que ,é um residuo obtido da destilação do vinho resultante da fermentação do caldo da cana, mosto de melaço ou mosto misto é amplamente utilizada para fins fertilização do solo para a cultura de cana-de-açúcar, tendo o potássio como maior constituinte mineral em porcentagem, levando a afirmar que que é rica neste elemento.

A composição da vinhaça é bastante variável e depende de uma série de fatores tais como: natureza e composição de matéria-prima; composição do mosto, tipo de fermentação e processo de destilação empregado (Almeida, 1962).

Entre os constituintes minerais, o patássio é o elemento que aparece em maior porcentagem, o que leva a afirmar que a vinhaça é um fertilizante rico neste elemento.

A composição de diferentes tipos de vinhaça são apresentadas na Tabela 5 , a qual varia em função do tipo da vinhaça (melaço/caldo). As quantidades de cada elemento foram expressos em elementos estão calculados em quilogramas por metro cúbico de vinhaça (Glória et al., 1976). 
Tabela 5. Composição média de diferentes tipos de vinhaça $\left(\mathrm{Kg} \cdot \mathrm{m}^{-\mathrm{s}}\right)$

\begin{tabular}{llll}
\hline Variáveis & melaço & caldo & melaço + caldo \\
$\mathrm{N}$ & 1,20 & 0,30 & 0.70 \\
$\mathrm{P}_{2} \mathrm{O}_{5}$ & 0,15 & 0,13 & 0,11 \\
$\mathrm{~K}_{2} \mathrm{O}$ & 7,80 & 1,20 & 4,60 \\
$\mathrm{CaO}$ & 3,60 & 0,70 & 1,70 \\
$\mathrm{MgO}$ & 1,00 & 0,20 & 0,70 \\
$\mathrm{SO}_{2}$ & 6,40 & 0,60 & 3,70 \\
$\mathrm{C}$ & 19,20 & 5,90 & 11,50 \\
Mat. Orgânica & 63,40 & 19,50 & 38,00 \\
\hline Relação C/N & 16,00 & 19,70 & 16,40
\end{tabular}

Fonte: Gloria et al. (1976)

Gloria \& Magro (1977), aplicando vinhaça por sulcos de infiltração, verificaram efeito benéfico do resíduo na produtividade agrícola da cana-de-açúcar, tanto na cana planta, como nas soqueiras subsequentes.

Magro \& Gloria (1977), aplicando vinhaça de mosto de melaço por gravidade na dose de $35 \mathrm{~m}^{3} \cdot \mathrm{ha}^{-1}$, complementada com fósforo solúvel, constataram um aumento de produtividade em diferentes variedades de cana-de-açúcar mesmo em comparação com a adubação mineral (NPK), o que indicou a possibilidade de substituição da adubação mineral das soqueiras pela adição da vinhaça. A aplicação do fosfato provocou efeito depressivo na produtividade da cultura e de açúcar (pol) por unidade de área.

A COPERSUCAR (1980) estudando os efeitos da aplicação de vinhaça à soqueira de cana-de-açúcar, em três anos consecutivos, constatou aumentos na produtividade de peso de cana e de açúcar, principalmente até a dosagem de $90 \mathrm{~m}^{3}$.ha ${ }^{-1}$ com tendência de estabilização e até decréscimo na dosagem mais elevada $\left(180 \mathrm{~m}^{3}\right.$.ha $\left.{ }^{-1}\right)$ em dois dos três anos considerados na pesquisa.

A elevação na produtividade da cana-de-açúcar, evidenciou-se tanto na 
aplicação de altas como de baixas dosagens de vinhaça, mas ocorrendo em conseqüência um maior desenvolvimento vegetativo motivado pela adição ao solo de matéria orgânica e elementos minerais, em especial o K. Em decorrência disto, o processo de maturação e a qualidade tecnológica da cana-de-açúcar poderão ser afetados, principalmente em dosagens elevadas (Silva \& Gurgel, 1981).

Estudando os efeitos de vinhaça ap!icados como fertilizante em cana-deaçúcar, a COPERSUCAR (1980) observou um aumento nas cinzas\%Brix e um decréscimo na pureza aparente. A aplicação de vinhaça, de um modo geral, atrasou o início de maturação, os valores da pol\%cana e açúcares redutores\%caldo mostraram uma tendência a se igualar aos valores da adubação mineral na época da colheita.

Para o caldo, César et al. (1978) salientam que o uso da vinhaça faz com que aumente o teor de potássio dos caldos e consequentemente o de cinzas, assim como o de amido, os quais são compostos melassigênicos.

Conforme Brieger ( 1979), citando Honig, os sais responsáveis pelo teor de cinzas nos caldos reduzem a taxa de cristalização, implicando na qualidade e produção de açúcares.

Em relação à fermentação alcoólica, os teores de potássio no caldo de cana, é considerado ideal, na faixa de 700 a 1200 ppm de $\mathrm{K}^{-}$(Amorim, 1985). 


\section{MATERIAIS E MÉTODOS}

\subsection{Características gerais do local, do composto de lixo domiciliar e do cultivar de cana de açúcar.}

\subsubsection{Localização}

O experimento foi levado a efeito em área do Departamento de Agroindústria,Alimentos e Nutrição, ESALQ/USP, situada no Município de Piracicaba, Estado de São Paulo, cujas coordenadas geográficas médias são: $22^{\circ} 42^{\prime}$ de Latitude Sul; $42^{\circ} 25^{\prime}$ de Longitude Oeste; $580 \mathrm{~m}$ de altitude.

\subsubsection{Clima}

A região de Piracicaba, SP apresenta clima característico do tipo CWA (segundo classificação de Koeppen) tropical úmido, com inverno seco (junho-julhoagosto), verão chuvoso e quente.

\subsubsection{Características de fertilidade do solo}

O experimento foi instalado em solo de média fertilidade natural, caracterizado como TR1-Terra Roxa Estruturada, Eutrófica, A moderado, Textura argilosa, muito argilosa (Classificação USDA: Kandiudalfic Eutrudox)

A análise quimica prévia de amostras compostas retiradas antes da 
instalação do ensaio à profundidades de $0-20 \mathrm{~cm}$ e de $20-40 \mathrm{~cm}$, apresentados na Tabela 6 .

Tabela 6. Análise quimica e fisica do solo da área experimental.

\begin{tabular}{lllllllllll}
\hline Prof. & M. O. & $\mathrm{pH}$ & $\mathrm{Ca}^{2-}$ & $\mathrm{Mg}^{2-}$ & $\mathrm{K}^{-}$ & $\mathrm{H}+\mathrm{Al}$ & $\mathrm{SB}$ & $\mathrm{CTC}$ & $\mathrm{V}$ & P-resina \\
$\mathrm{cm}$ & $\mathrm{g} / \mathrm{kg}$ & $\mathrm{CaCl}_{2}$ & \multicolumn{2}{c}{$\mathrm{mmol} / \mathrm{dm}^{3}$ de terra } & & & & $\%$ & $\mathrm{mg} / \mathrm{dm}^{3}$ \\
$0-20$ & 18,9 & 5,15 & 69,0 & 18,0 & 2,15 & 58,0 & 89,2 & 147, & 60,6 & 19,0 \\
$20-50$ & 12,6 & 5,45 & 82,0 & 13,0 & 0,95 & 42,0 & 96,0 & 138, & 69,6 & 11,0 \\
\hline
\end{tabular}

Aos 120 dias após o plantio, foram coletadas as amostras de solo das 51 parcelas para o fim da obtenção da fertilidade do solo após a aplicação dos adubos orgânico e quimicos.

\subsubsection{Composição do composto de lixo}

O material oriundo da Estação de Compostagem da Vila Leopoldina de São Paulo, SP, foi transportado para o Departamento de Agroindústria, Alimentos e Nutrição onde se procedeu a compostagem. Esse material amontoado em leira de $3 \times 15 \times 1 m$ era revolvido a cada cinco dias, para que a compostagem fosse aeróbica. Após 50 dias, quando a temperatura se estabilizou, considerou-se encerrado o processo de transformação.

Os dados da análise de metais pesados do composto de lixo empregado, estão dentro das faixas de teores considerados aceitáveis pela EPA (1983) e pela CETESB para uso em solos agricolas.

A composição média do composto de lixo domiciliar curado, referentes à média de duas amostras é apresentada na Tabela 7, expressos em quantidades dos componentes em gramas por quilograma do composto. 
Tabela 7. Composição média do composto de lixo utilizado no experimento

\begin{tabular}{|c|c|}
\hline Componentes & Concentração \\
\hline & $\mathrm{g} \cdot \mathrm{Kg}^{-1}$ \\
\hline Matéria orgânica & 234,1 \\
\hline Umidade Total & 464,8 \\
\hline Relação C/N & 16,25 \\
\hline Fósforo $\left(\mathrm{P}_{2} \mathrm{O}_{5}\right)$ & 2,5 \\
\hline Potássio $\left(\mathrm{K}_{2} \mathrm{O}\right)$ & 4,1 \\
\hline Enxofre (S) & 1,7 \\
\hline Cálcio $(\mathrm{Ca})$ & 16,2 \\
\hline Magnésio (Mg) & 4,8 \\
\hline \multirow[t]{2}{*}{ Carbono (C) } & 156,0 \\
\hline & $\mathrm{mg} \cdot \mathrm{Kg}^{-1}$ \\
\hline Cobre $(\mathrm{Cu})$ & 72,0 \\
\hline Cádmio (Cd) & 0,3 \\
\hline Cromo $(\mathrm{Cr})$ & 1,2 \\
\hline Chumbo $(\mathrm{Pb})$ & 8,2 \\
\hline Níquel (Ni) & 3,4 \\
\hline Zinco $(\mathrm{Zn})$ & 94,0 \\
\hline
\end{tabular}

\subsubsection{Cana-de-açúcar}

A variedade de cana-de-açúcar empregada foi a RB76-5418, a qual apresenta as seguintes características, segundo Arevalo (1993): rica e precoce, apresenta produtividade agrícola regular, não suportando solos mais pobres ou compactados. Os solos podzolizados são os mais adequados. É altamente resistente à ferrugem e a outras doenças como o carvão. Apresenta crescimento muito rápido, o que torna uma variedade que pode ser cortada com apenas 10 meses de idade, com alto teor de sacarose. Não 
floresce e o seu comportamento na indústria é muito bom. Possui baixa brotação.

\subsection{Delineamento experimental}

O delineamento experimental foi o de fatorial, $4 \times 2 \times 2$ com tratamento adicional segundo Gomes (1985), com 16 tratamentos e 3 repetições, totalizando 48 parcelas.

A parcela foi constituida de 5 linhas de 8 metros de comprimento, espaçadas nas entrelinhas em 1,30m (Silva et al., 1993). A área útil da parcela compreendeu as três linhas centrais com $6 \mathrm{~m}$ de comprimento, descontado a bordadura ( $1 \mathrm{~m}$ de cada lado), ou seja, uma área efetiva de amostragem de $23,4 \mathrm{~m}^{2}$.

Em face aos resultados de fertilidade do solo, calculou-se a recomendação de adubação NPK para a cana planta, baseado no Boletim 100 do IAC, usando-se como fertilizantes sulfato de amônio, superfosfato triplo e cloreto de potássio. A dosagem recomendada foi de $120 \mathrm{Kg}$.ha ${ }^{-1}$ tanto para $\mathrm{P}_{2} \mathrm{O}_{5}$ como para $\mathrm{KCl}$. Para a adubação com NPK usou-se a formulação (4-20-20) na base de $600 \mathrm{Kg}_{\mathrm{g}} \mathrm{ha}^{-}{ }^{1}$. O experimento foi implantado em 10/09/ 1996, em cultivo de cana de ano.

Os fertilizantes químicos foram aplicados no sulco de plantio, empregando todo o fósforo, potássio e nitrogênio. O composto de lixo foi aplicado do sulco de plantio.

Os tratamentos foram:

$$
\begin{aligned}
& \mathrm{T}_{01}=\text { Testemunha } \\
& \mathrm{T}_{02}=\mathrm{P}\left(120 \mathrm{Kg} \cdot \mathrm{ha}^{-1}\right) \\
& \mathrm{T}_{0:}=\mathrm{K}\left(120 \mathrm{Kg} \cdot \mathrm{ha}{ }^{-1}\right) \\
& \mathrm{T}_{04}=\mathrm{PK} \\
& \mathrm{T}_{05}=30 \mathrm{t} \cdot \mathrm{ha}^{-1} \text { de composto de lixo } \\
& \mathrm{T}_{06}=60 \mathrm{t} \cdot \mathrm{ha}^{-1} \text { de composto de lixo } \\
& \mathrm{T}_{07}=90 \mathrm{t} \cdot \mathrm{ha}^{-1} \text { de composto de lixo } \\
& \mathrm{T}_{08}=30 \mathrm{t} \cdot \mathrm{ha}^{-1} \text { de composto de lixo }+\mathrm{P}
\end{aligned}
$$




$$
\begin{aligned}
& \mathrm{T}_{09}=60 \mathrm{t} \cdot \mathrm{ha} \mathrm{a}^{-1} \text { de composto de lixo }+\mathrm{P} \\
& \mathrm{T}_{10}=90 \mathrm{t} \cdot \mathrm{ha} \mathrm{h}^{-1} \text { de composto de lixo }+\mathrm{P} \\
& \mathrm{T}_{11}=30 \mathrm{t} \cdot \mathrm{ha}^{-1} \text { de composto de lixo }+\mathrm{K} \\
& \mathrm{T}_{12}=60 \mathrm{t} \cdot \mathrm{ha}^{-1} \text { de composto de lixo }+\mathrm{K} \\
& \mathrm{T}_{13}=90 \mathrm{t} \cdot \mathrm{ha}^{-1} \text { de composto de lixo }+\mathrm{K} \\
& \mathrm{T}_{14}=30 \mathrm{t} \cdot \mathrm{ha}^{-1} \text { de composto de lixo }+\mathrm{PK} \\
& \mathrm{T}_{15}=60 \mathrm{t} \cdot \mathrm{ha}^{-1} \text { de composto de lixo }+\mathrm{PK} \\
& \mathrm{T}_{16}=90 \mathrm{t} \cdot \mathrm{ha} \mathrm{h}^{-1} \text { de composto de lixo }+\mathrm{PK}
\end{aligned}
$$

\subsection{Amostragens e colheitas}

As amostragens de colmos das parcelas ocorreram nos meses de julho, agosto, setembro e outubro de 1997, adotando-se como critério a coleta de 10 colmos em seqüência e ao acaso, em uma das três linhas centrais da parcela, não houve escolha do local da retirada das amostras, foram ao acaso. Tais amostras foram devidamente enfeixadas e etiquetadas. Os colmos foram despalhados e despontados no laboratório.

\subsubsection{Preparo das amostras de massa vegetal}

As amostras de biomassa fresca da parte aérea foram desagregadas em desintegrador tipo forrageiro e homogeneizadas em betoneira.

Das amostras de cana já desintegradas retirou-se subamostras de $500 \mathrm{~g}$ para a extração do caldo, através da prensa hidráulica (Tanimoto, 1964), obtendo-se então o caldo extraído (CE) e o bagaço fibroso da prensa, que foram empregados na determinações dos parâmetros tecnológicos. Com os resultados procederam-se os cálculos, conforme encontra-se em Cesar \& Silva (1993). 


\subsection{Análises tecnológicas}

\subsubsection{Brix \% do caldo extraído (Brix \% CE)}

Determinado por refratometria a $20^{\circ} \mathrm{C} / 20^{\circ} \mathrm{C}$ (Schneider, 1979).

\subsubsection{Pol \% do caldo extraído (Pol \% CE)}

Dosada pelo método de Schmitz sem diluição, segundo ICUMSA (Schneider, 1979).

\subsubsection{Pureza aparente CE}

Calculada pela relação entre Pol \% CE/Brix \% CE x 100.

\subsubsection{Açúcares redutores \% caldo extraído (AR \% CE)}

Expressos em glicose, dosados pelo método de Lane \& Eynon, (1934).

\subsubsection{Cinzas\%caldo extraído (Cinzas\%CE)}

Dosado pelo método da rafinômetro de Buse-Todt - Gollnow (Browne \& Zerban, 1941).

\subsubsection{Potássio}

Determinado pelo método fotométrico de chama de emissão, segundo Instituto Adolfo Lutz, (1985), expresso em mg de $\mathrm{K}_{2} \mathrm{O}$ por litro. 


\subsubsection{Fósforo}

Determinado pelo método colorimétrico (Delgado \& Cesar, 1984), expresso em mg de $\mathrm{P}_{2} \mathrm{O}_{5}$ por litro.

\subsection{Transformação dos resultados \%caldo em \%cana}

\subsubsection{Fibra \% Cana (F)}

Utilizada a metodologia de Tanimoto (1964) adaptada por Sturion \& Fernandes (1979), segundo a fórmula:

Fibra \% Cana $=\frac{(100-\mathrm{PBS})-(\mathrm{PBU} \times \mathrm{Brix} \% \mathrm{CE})}{5 \times(100-\mathrm{Brix} \% \mathrm{CE})}$

PBU- Peso do bolo úmido PBS- Peso do bolo seco

\subsubsection{Pol \% Cana}

Segundo Cesar \& Silva (1993), através da seguinte expressão:

$\mathrm{Pol} \% \mathrm{Cana}=\mathrm{Pol} \% \mathrm{CE} \times \mathrm{FS}$

onde: $F S=0,94283-0,010469 \times F$

\subsubsection{Brix \% Cana}

Segundo Cesar \& Silva (1993), através da seguinte expressão: 
Brix $\%$ Cana $=$ Brix $\% \mathrm{CE} \times \mathrm{FB}$

onde: $\mathrm{FB}=1,01083-0,01240 \mathrm{~F}$

\subsubsection{Açúcares Redutores \% Cana (AR\%Cana)}

Segundo a equação: $\mathrm{AR} \% \mathrm{Cana}=\mathrm{AR} \% \mathrm{CE} \times \mathrm{FS}$

\subsection{Peso de cana por hectare}

Determinou-se o peso médio de 10 colmos e conhecendo-se o número de colmos por metro linear por tratamento e considerou-se também os colmos retirados nas amostragens. A partir destes dados chegou-se à estimativa de produtividade em julho, agosto e setembro calculou-se a produtividade em quilos de cana por hectare, quando o espaçamento foi de $1,30 \mathrm{~m}$. Na última época, coletou-se as parcelas e obteve-se a produtividade real dos tratamentos.

\subsection{Peso de açúcar por hectare}

Conhecendo o peso de cana por hectare e a pol da cana calculou-se a produção em quilos de açúcar por hectare 


\section{RESULTADOS E DISCUSSÃO}

\subsection{Condições Agrometeorológicas durante o Experimento}

A precipitação média foi adequada ás da necessidades da cultura, no periodo compreendido de maio até outubro de 1997, ocorrendo maturação natural dos colmos da cultura da cana-de-açúcar.

\subsection{Composto de Lixo: Composição e Legislação}

Pela composição média de macronutrientes do $\mathrm{CL}$, constatou-se teores relativos de potássio mais elevados, em relação aos demais nutrientes (Cravo, 1995; Grossi, 1993). No tocante à composição do CL em micronutrientes e metais pesados como pode ser observado na Tabela 7 (no item 3.1.4.), constatou-se que os teores de metais eram muito abaixo do que o residuo usado nos Estados Unidos e paises da Europa (Grassi, 1993). Do ponto de vista da Legislação, ao comparar-se a composição do CL usado no ensaio com as especificações de uso e disposição agrícola deste, verificou-se que o residuo urbano preenche as normas estabelecidas pela Agência Americana de Proteção a o Meio Ambiente no Registro Federal de 19/03/1993 (53 FR [32]: 9248-9415) na 40C FR parte 403 (Estados Unidos, 1993).

\subsection{Composto de Lixo Urbano e a Fertilidade do Solo}

A análise química das amostras de terra coletadas antes da aplicação do 
composto de lixo (Tabela 6), revelou tratar-se de solo com médios teores trocáveis de Mg e K, moderada acidez e baixo teor de P no solo TE (Raij et al., 1985).

Nas Figuras 1 e 2 encontram-se os resultados dos efeitos da adição do CL sobre o comportamento dos parâmetros de fertilidade do solo $(\mathrm{pH}, \mathrm{H}+\mathrm{Al}, \mathrm{SB}, \mathrm{V} \%$, CTC, Ca e Mg). Ocorreram efeitos significativos para a adição do CL $\left(\mathrm{F}^{* *}\right.$ ) (Figuras 1 e 2) e para as seguintes variáveis de solo: $\mathrm{pH}$ em $\mathrm{CaCl}_{2}$; acidez potencial $(\mathrm{H}+\mathrm{Al})$; soma (SB) e saturação (V) de bases; capacidade de troca catiônica (CTC); cálcio (Ca ${ }^{\cdots}$ ) e magnésio $\left(\mathrm{Mg}^{+++}\right)$. Procederam-se os desdobramentos estatísticos e os gráficos foram elaborados apenas para as variáveis de solo onde a adubação com CL e as interações CL $\mathrm{X}$ adubaçōes químicas foram significativas.

De acordo com o critério de Gomes (1985) os coeficientes de variação obtidos para o efeito do fator tratamento nos indicadores de fertilidade do solo podem ser considerados como baixo $(<10 \%)$ para $\mathrm{pH}$, médios $(10$ a $20 \%)$ para $\mathrm{H}^{-*}+\mathrm{Al}^{+3}, \mathrm{CTC}$ e V\% e altos ( 20 a 30\%) para P-resina, $\mathrm{K}^{+}, \mathrm{Ca}^{2+}, \mathrm{Mg}^{2+}$ e SB.

A primeira ação do CL aplicado neutralizou a acidez potencial, provocando aumento do $\mathrm{pH}$ do solo (Figura 1a), o que já havia sido observado na literatura (Messias \& Morais, 1992; Collier et al., 1992; Parra et al., 1997). A CTC e a saturação por bases tiveram seus valores aumentados com o aumento da dose de CL (Figura $2 \mathrm{a}$ e $1 \mathrm{c}$ ), mas foram valores moderados de ação do CL no solo (Berton \& Valadares, 1991). A ação corretiva da acidez do CL foi relativamente moderada sobre o solo TE, pois houve a necessidade de aplicar 60 t.ha ${ }^{-1}$ de CL para elevar em apenas 0,3 unidades de $\mathrm{pH}$ ou pouco mais de $10 \%$ na saturação por bases. A aplicação de 60 t.ha ${ }^{-1}$ de CL foi suficiente para passar os macronutrientes ( $\mathrm{P}$ e $\mathrm{K}$ ) para classes de teores altos (Raij et. al., 1985) sendo mais que suficiente para atender as necessidades da cultura de cana-de-açúcar. Tal fato refletiu em um valor de saturação por bases próximos a $65 \%$ (Figura 1d) e um acréscimo da CTC do solo (Figura 2a) o que está de acordo com o relatado por Berton \& Valadares (1991).

A Segunda ação do CL foi como fornecedor de nutrientes (Figura 3). Verificou-se que a elevação de teores de K e P no solo ocorreu pela adição de CL, o que 
já havia sido observado na literatura (Santos \& Stamford, 1991; Moraes \& Selbach, 1991; Mazur et al., 1983; Parra et al., 1997). O teor de P e K nos compostos de lixo urbano (Tabela 7) são consideravelmente mais altos do que aqueles encontrados na maioria dos solos agricolas (DeHaan, 1981).

Quanto ao efeito desta adição de fósforo, verifica-se na Figura $3 a$ que há aumento considerável no teor do elemento, pcis passou de teores considerados baixos $(<15)$ para teores médios (Raij et al., 1985), até mesmo quando a menor dose de CL foi aplicada. Resultados semelhantes foram obtidos por Moraes \& Selbach (1991). Isto demonstra que, pelo menos em parte, o $\mathrm{P}$ do $\mathrm{CL}$ foi disponivel aos vegetais. Quanto à complementação do $\mathrm{CL}$ com $\mathrm{P}$, pode-se verificar pelos resultados analíticos do solo que não haveria necessidade, pois o CL ao ser aplicado em quantidades de $30 \mathrm{t}^{\mathrm{ha}^{-1}}$ já forneceria quantidades suficientes deste nutriente ao solo, para se ter niveis compativeis com a exigência da planta.

Quanto ao efeito do K via CL pode-se dizer que a adubação potássica, em complementação ao uso de CL (Figura 3b) não era necessária pois esse residuo é rico nesse macronutriente e o solo já possuía um teor original médio ao nivel de $\mathrm{K}^{-}$que é suficiente à cultura (Raij et al., 1985). Devido a este aspecto pode-se deduzir que a riqueza de $\mathrm{K}$ no $\mathrm{CL}$ poderia limitar a sua aplicação como fertilizante em doses mais elevadas para este solo (Collier et al., 1992; Moraes \& Selbach, 1991). 


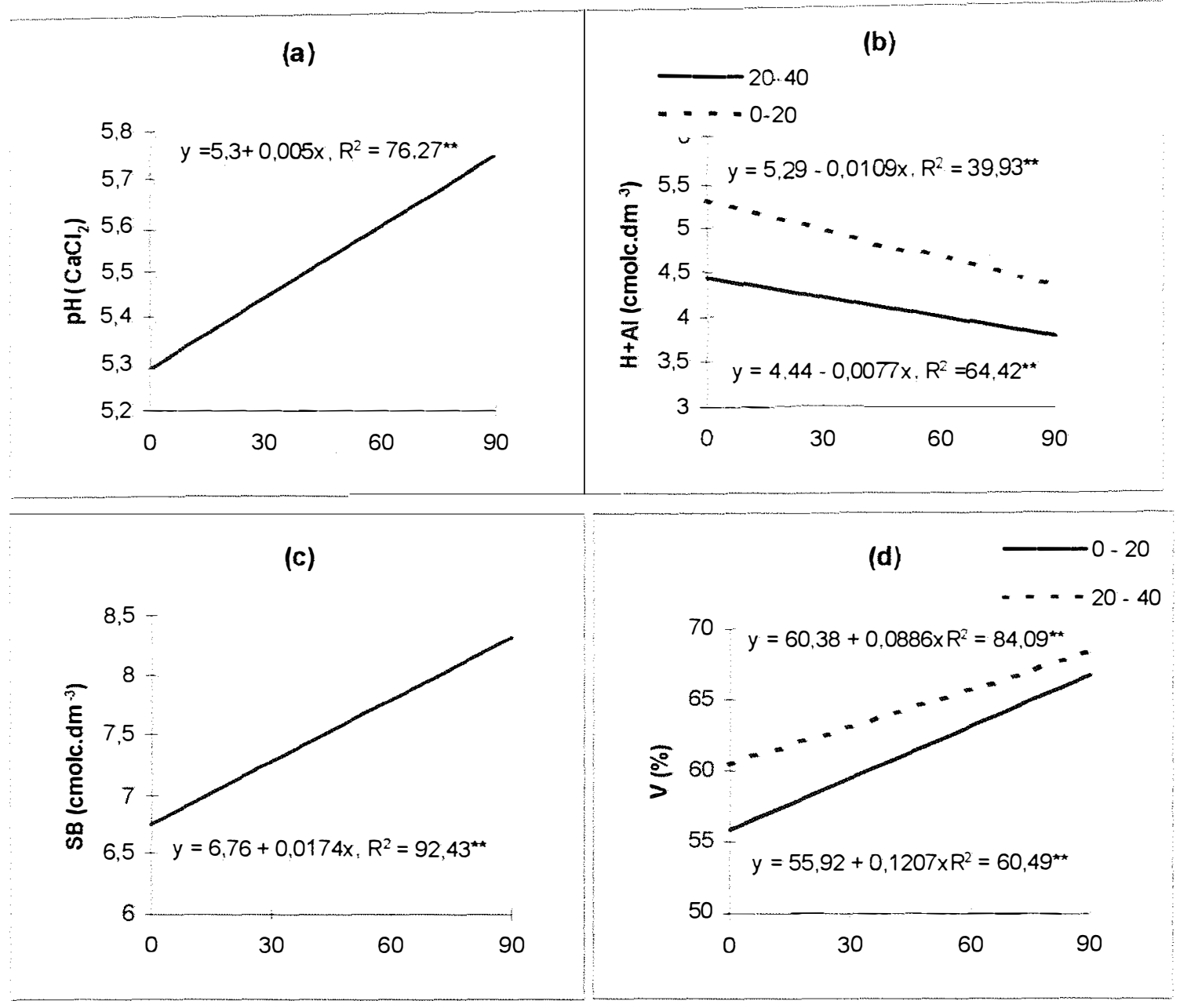

Composto de Lixo Urbano, $\mathrm{t} \mathrm{ha}^{-1}$

Figura 1. Influência da aplicação de doses de composto de lixo na correção da acidez do solo, medida pelas acidez ativa $(\mathrm{a}=\mathrm{pH})$ e potencial $(\mathrm{b}=\mathrm{H}+\mathrm{Al})$, da soma $(\mathrm{c}=$ $\mathrm{SB})$ e na saturação por bases $(\mathrm{d}=\mathrm{V})$ aos 120 dap. ${ }^{*}$-significativo a $5 \%$ de probabilidade no teste $\mathrm{F} ;{ }^{* *}$-significativo a $1 \%$ de probabilidade no teste $\mathrm{F}$; NS-não significativo no teste $\mathrm{F}$. 
(a)

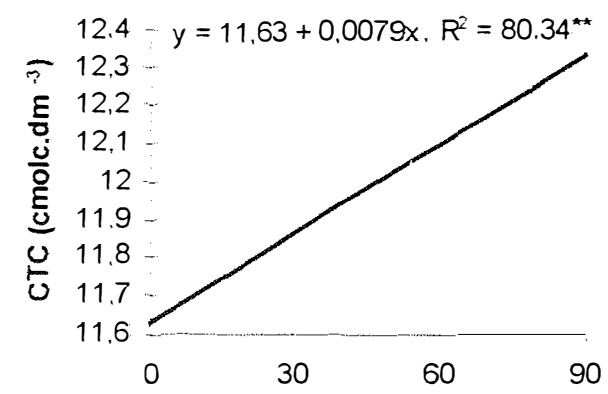

(b)

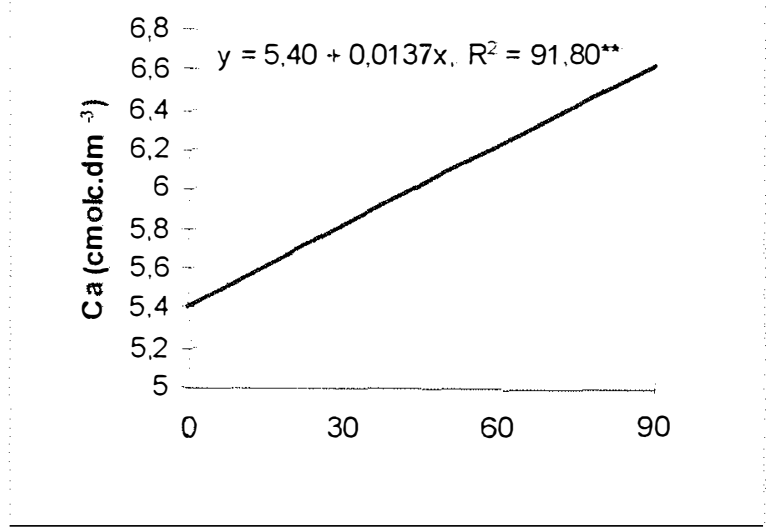

(c)

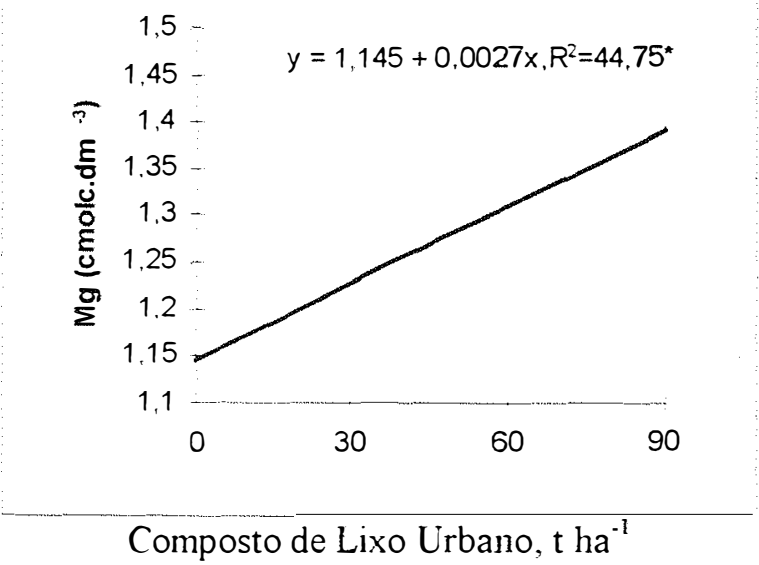

Figura 2. Influência da aplicação de doses de composto de lixo na capacidade de troca de cátions $(a=C T C)$ e teores de cálcio $(b=C a)$ e de magnésio $(c=M g)$ aos 120 dap. ${ }^{*}$-significativo a $5 \%$ de probabilidade no teste $\mathrm{F} ;{ }^{* *}$ - significativo a $1 \%$ de probabilidade no teste $\mathrm{F}$; NS-não significativo no teste $F$. 

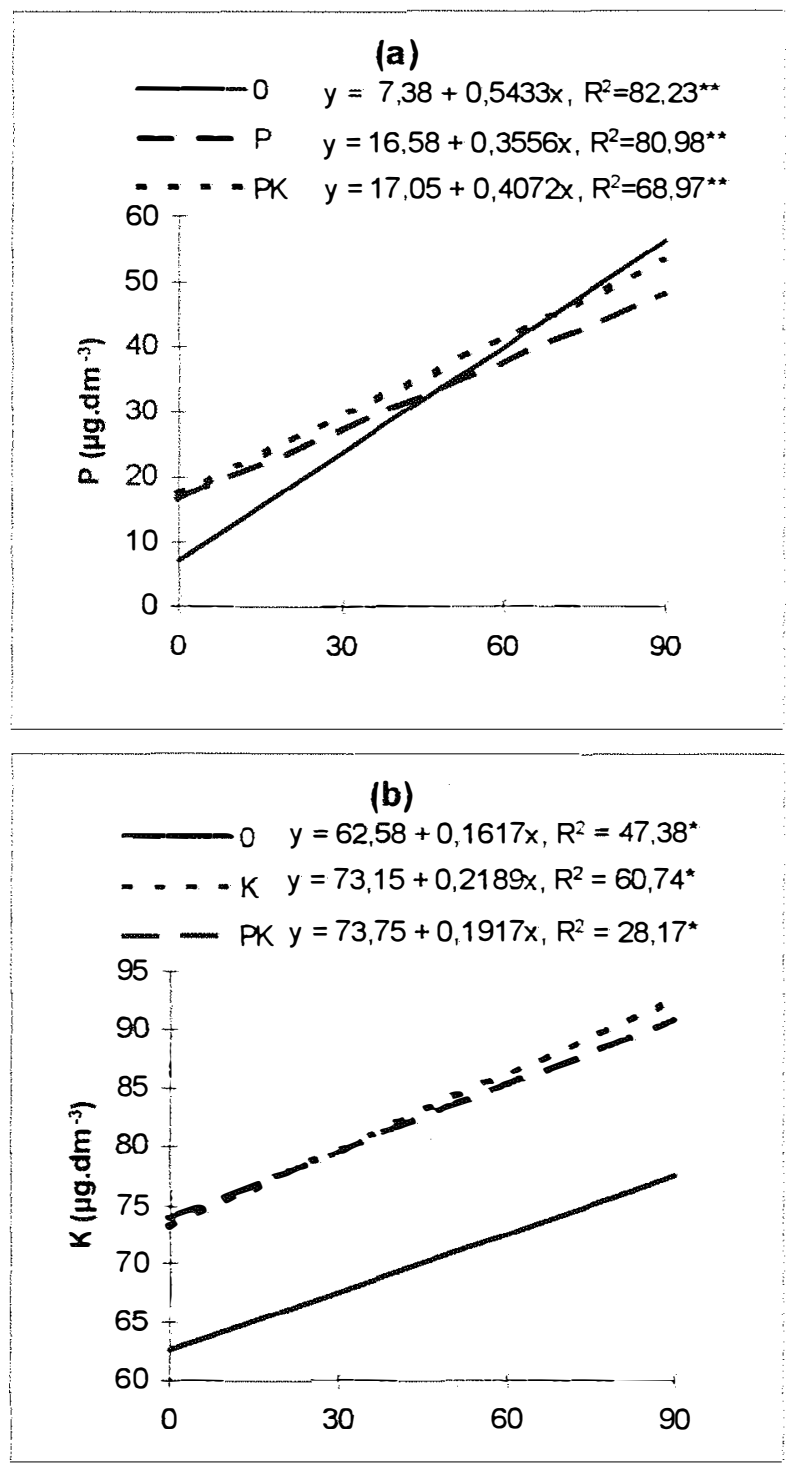

\section{Composto de Lixo Urbano, tha ${ }^{-1}$}

Figura 3. Influência da aplicação de doses de composto de lixo nos teores de fósforo $(a=P)$ e de potássio $(b=K)$, com e sem interação com a fonte mineral do elemento $\left(0, \mathrm{P}, \mathrm{K}\right.$ e PK) ${ }^{* *}$ - significância a $1 \%$ de probabilidade no teste $\mathrm{F} ;$ * -significância de $5 \%$ de probabilidade no teste F; NS-não significativo no teste F. 


\subsection{Efeitos da aplicação de CL nas caracteríticas tecnológicas da cana}

Os resultados a seguir foram obtidos da média de 3 repetições, realizados no decorrer do experimento. A partir dos dados analiticos e das suas interpretações estatisticas, foram evidenciadas as seguintes observações:

Os coeficientes de variação do Brix, Pol, Fibra, AR, Umidade, Cinzas, ATR foram de $7,42,2,10,3,51,23,17,0,70,8,35$ e 2,96\%, respectivamente. Esses valores encontrados são baixos pois, segundo Gomes (1985), para fins de experimentação agrícola eles satisfazem quando são inferiores a $20 \%$.

\subsubsection{Brix na cana}

Os valores de Brix são de grande importância por ser considerado fator determinante no julgamento da qualidade da cana pela correlação que existe com a Pol.

Os resultados para o Brix bem como as demais caracteristicas tecnológicas da cana, não mostraram significância quando do estudo entre $\mathrm{CL}$ e as interações com adubação quimicas, deste modo as interpretações serão genéricas.

Os dados obtidos para Brix na cana, nas diferentes dosagens de $\mathrm{CL}$ empregadas $\left(0,30,60,90\right.$ t.ha $\left.^{-1}\right)$ são apresentadas na Tabela 8. Em termos médios os valores oscilaram entre 16,64 e 18,40. A aplicação do teste $F$ entre as épocas obteve valor significativo ao nivel de $1 \%$ de probabilidade e valor não significativo para as doses dentro das épocas. Houve a tendência de aumentar o Brix na cana no decorrer das 4 épocas amostradas, devendo-se a isso uma ocorrência natural na cultura da cana-de-açúcar quando na época de maturação, onde há uma maior concentração de sólidos solúveis no caldo dos colmos 
Tabela 8. Valores médios obtidos para Brix na cana ${ }^{1}$ em função da adição de doses $\left(\right.$ t. ha $\left.{ }^{\mathrm{l}}\right)$ de composto de lixo no decorrer das épocas, em dias após a sua aplicaçào.

\begin{tabular}{ccccc}
\hline Doses & \multicolumn{4}{c}{ Épocas, dias } \\
\cline { 2 - 5 } CL & 303 & 334 & 365 & 395 \\
\hline 0 & 16,64 & 17,27 & 18,35 & 17,83 \\
30 & 16,85 & 17,59 & 18,40 & 17,86 \\
60 & 16,92 & 17,52 & 17,80 & 17,84 \\
90 & 17,17 & 17,59 & 18,35 & 17,61 \\
\hline
\end{tabular}

Média de 3 repetiçōes $\mathrm{CV}=7,42 \%$ 
(a)

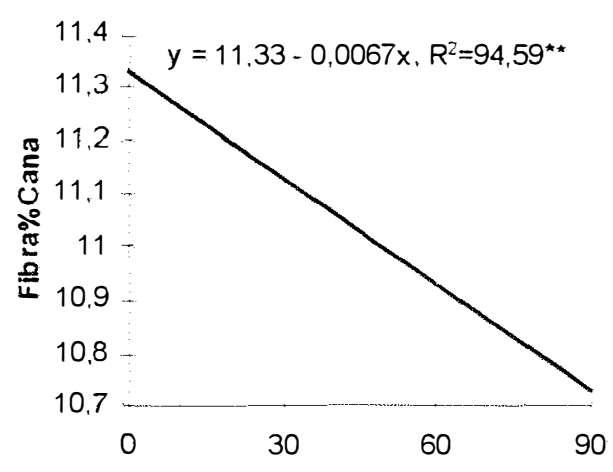

(b)

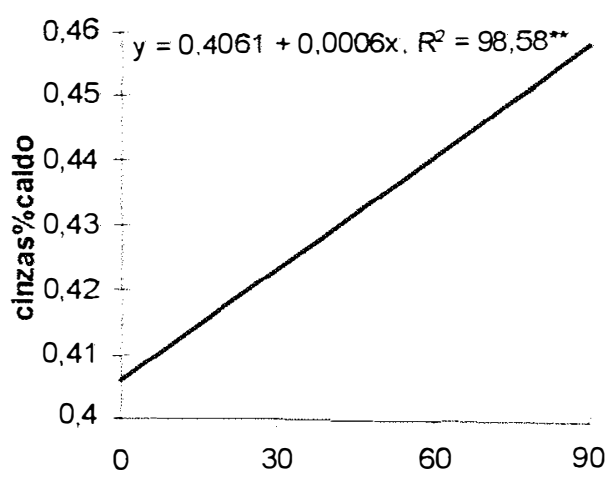

(c)

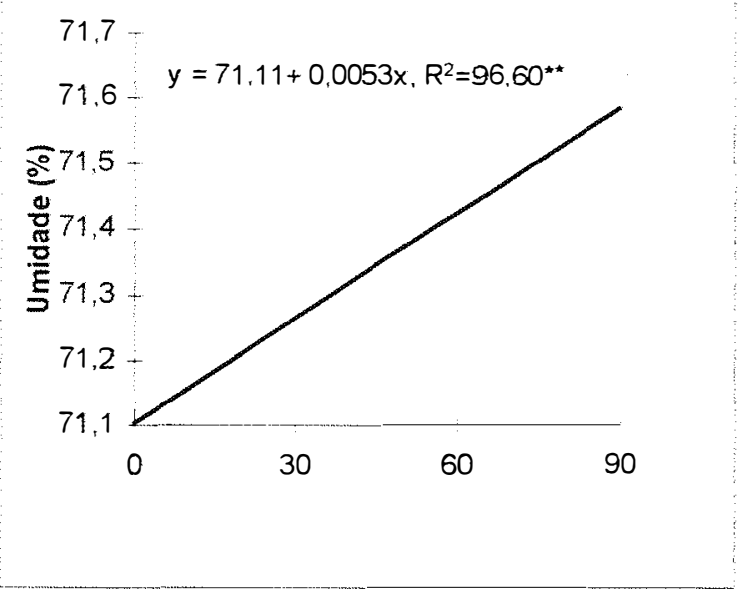

Composto de lixo Urbano, tha ${ }^{-1}$

Figgura 4. Influência da aplicação de composto de lixo ao solo sobre as caracteristicas tecnológicas da cana-de-açúcar ( $a=f i b r a ; b=$ cinzas; $c=$ umidade). *- significativo a $5 \%$ de probabilidade no teste $\mathrm{F}$; **- significativo a $1 \%$ de probabilidade no teste $\mathrm{F}$. 


\subsubsection{Pol na cana}

A determinação da Pol é um fator de grande importância refletindo diretamente no rendimento em açúcar e álcool durante a industrialização.

Os índices obtidos para Pol na cana, em colmos produzidos nas diferentes doses de $\operatorname{CL}\left(0,30,60\right.$ e 90 t.ha $\left.^{-1}\right)$ são apresentados na Tabela 9. A aplicação do teste F entre as 4 épocas amostradas apresentou valor significativo para o fator época em $1 \%$ de probabilidade. A Pol na cana tendeu a aumentar seus valores no decorrer das épocas.

Tabela 9. Valores médios obtidos para Pol na Cana ${ }^{1}$ em função das doses de composto de lixo no decorrer das épocas, em dias após a sua aplicação.

\begin{tabular}{ccccc}
\hline Doses & \multicolumn{4}{c}{ Épocas, dias } \\
\cline { 2 - 5 } CL & 303 & 334 & 365 & 395 \\
\hline 0 & 14,25 & 14,90 & 15,78 & 15,54 \\
30 & 14,49 & 15,24 & 15,72 & 15,54 \\
60 & 14,57 & 15,24 & 15,38 & 15,50 \\
90 & 14,79 & 15,20 & 15,68 & 15,24 \\
\hline
\end{tabular}

T'Média de 3 repetições $\mathrm{CV}=2,10 \%$

Para o fator $\mathrm{CL}$ não apresentou valor significativo no teste $\mathrm{F}$ para as doses empregadas isoladamente mas, quando complementado com a adubação $\mathrm{P}$ e/ou $\mathrm{K}$ houve significância ao nível de $1 \%$ de probabilidade, como seguem os modelos ajustados de resposta ao $\mathrm{CL}$ :
a) Sem adição: $Y=15,05+0,0029 . X\left(R^{2}=80,35^{* *}\right)$
b) Adição de $\mathrm{K}$ : $\mathrm{Y}=15,23+0,0077 . \mathrm{X}-0,0001 \mathrm{x}^{2}\left(\mathrm{R}^{2}=93,97^{* *}\right)$
c) Adição de PK: $\mathrm{Y}=14,92+0,0044 . \mathrm{X}\left(\mathrm{R}^{2}=73,63^{* *}\right)$

As crescentes dosagens dentro de épocas não causou redução da pol na cana, não prejudicando sua industrialização.

A resposta da cultura de cana em acumulação de açúcar nos colmos 
mostrou-se significativa para a adição do $\mathrm{CL}+$ fosfato ou 30 t.ha $^{-1}$ de $\mathrm{CL}+$ potássio (Tabela 10).

Tabela 10. Efeitos da adição combinada de doses de composto de lixo e de suplementação P,K e PK na Pol na cana (média de julho a outubro de 1997).

\begin{tabular}{|c|c|c|c|c|c|c|}
\hline \multicolumn{2}{|c|}{ Doses de CL, t. ha ${ }^{-1}$} & \multicolumn{4}{|c|}{ Fertilizantes Químicos } & \multirow{2}{*}{$\begin{array}{l}\text { Médias de } \\
\text { doses CL }\end{array}$} \\
\hline & & $\begin{array}{c}\text { Sem adição } \\
(00)\end{array}$ & $\mathrm{P}$ & $\mathrm{K}$ & $\mathrm{PK}$ & \\
\hline \multicolumn{2}{|c|}{00} & $15,00 \mathrm{a}$ & $15,32 \mathrm{ab}$ & $15,21 \mathrm{a}$ & $14,93 \mathrm{~b}$ & $15,12 \mathrm{a}$ \\
\hline \multicolumn{2}{|c|}{30} & $15,21 \mathrm{a}$ & $15,26 \mathrm{ab}$ & $15,40 \mathrm{a}$ & $15,12 \mathrm{ab}$ & $15,25 \mathrm{a}$ \\
\hline \multicolumn{2}{|c|}{60} & $15,19 a$ & $15,54 \mathrm{a}$ & $15,26 \mathrm{a}$ & $15,04 \mathrm{~b}$ & $15.26 \mathrm{a}$ \\
\hline \multicolumn{2}{|c|}{90} & $15,30 \mathrm{a}$ & $15,15 b$ & $15,07 \mathrm{a}$ & $15,39 a$ & $15,23 \mathrm{a}$ \\
\hline \multicolumn{2}{|c|}{ Média de Fertiliz. } & $15,18 \mathrm{a}$ & $15,32 \mathrm{a}$ & $15,24 \mathrm{a}$ & $15,12 \mathrm{a}$ & 15.22 \\
\hline Causas de & $\mathrm{CL}$ & \multicolumn{4}{|c|}{ NS } & \\
\hline Variação & Química & \multicolumn{4}{|c|}{$* *$} & \\
\hline (Valor F) & $\mathrm{CL} \times \mathrm{Q}$ & \multicolumn{4}{|c|}{$*$} & \\
\hline \multicolumn{2}{|c|}{$\mathrm{CV} \%$} & \multicolumn{4}{|c|}{2,10} & \\
\hline
\end{tabular}

$\mathrm{CL}=$ composto de lixo urbano; ${ }^{*} \mathrm{e}^{* *}=$ significativo a $5 \%$ e $1 \%$ de probabilidade no teste F.

\subsubsection{Açúcares Redutores\%Cana}

Este elemento, como o Brix e a pol, é determinante no julgamento da qualidade da cana-de-açúcar visando o seu processamento.

Os Açúcares Redutores \% Cana, para as diferentes doses de CL (0, 30, 60, 90 t. ha $^{-1}$ ) tem seus valores apresentados na Tabela 11. As médias das doses variaram de 0,20 a 0,47 sendo que a aplicação do teste $F$ apresentou valor significativo ao nivel de $1 \%$ de probabilidade apenas entre as épocas, onde houve a tendència de diminuir seu teor 
no decorrer das épocas

Tabela 11. Valores médios obtidos para $\mathrm{AR} \% \mathrm{Cana}^{1}$ em função da aplicação de doses $\left(\right.$ t.ha $\left.^{-1}\right)$ de composto de lixo no decorrer das épocas em dias após a sua aplicação

\begin{tabular}{ccccc}
\hline Doses & \multicolumn{4}{c}{ Épocas, dias } \\
\cline { 2 - 5 } CL & 303 & 334 & 365 & 395 \\
\hline 0 & 0,47 & 0,43 & 0,53 & 0,31 \\
30 & 0,43 & 0,39 & 0,60 & 0,29 \\
60 & 0,41 & 0,40 & 0,47 & 0,30 \\
90 & 0,37 & 0,37 & 0,54 & 0,34
\end{tabular}

${ }^{1}$ Média de 3 repetições $\mathrm{CV}=23,17 \%$

\subsubsection{Fibra e Umidade\%Cana}

O teor de fibra na cana é um fator determinante na eficiência do processo pois, ele influencia diretamente na capacidade de moagem e na extração de sacarose.

Para as doses de CL $\left(0,30,60,90 t^{t} \cdot h^{-1}\right)$, os valores da Fibra na cana são apresentadas na Tabela 12, onde os valores médios oscilaram entre 10,45 a 11,72. A aplicação do teste $F$ para o fator épocas não obtiveram valores significativos e para as diferentes doses do $\mathrm{CL}$ resultou um valor de $\mathrm{F}$ significativo ao nível de $1 \%$ de probabilidade, ajustando o modelo $\mathrm{Y}=11,33-0,0067 \cdot \mathrm{X}\left(\mathrm{R}^{2}=94,59 * *\right)$ com a tendência de diminuir os valores de fibra sobre os colmos conforme o acréscimo de doses (Figura 4a). Também não houve interação $\mathrm{CL} X$ adubo (P, K e PK), como demonstrouse no teste F. O decréscimo da Fibra \% Cana se explica pelo aumento linear da Umidade \% Cana, que obteve valores crescentes para as mesmas doses de CL com uma oscilação das médias entre 69,94 e 71,95 nas 4 épocas amostradas, com uma tendência de diminuir no decorrer do tempo, com um valor do teste $F$ significativo ao nivel de $1 \%$ de probabilidade (Tabela 13). De um modo geral, na média de todas as épocas mesmo fato 
ocorreu para o fator $\mathrm{CL}$, quando empregou suas doses $\left(0,30,60\right.$ e $\left.90 \mathrm{t} \cdot \mathrm{ha}^{-1}\right)$ com o modelo ajustado $Y=71,11-0,0053 . X\left(R^{2}=96,60 * *\right)$ Houve a tendência de aumentar o teor de umidade nos colmos, conforme o acréscimo das doses quais seguem: 71,11 , $71,26,71,42$ e $71,58 \%$, respectivamente (Figura $4 \mathrm{c}$ )

Tabela 12. Valores médios obtidos para Fibra \% Cana ${ }^{1}$ em funçào da adição de doses $\left(\right.$ t.ha $\left.{ }^{-1}\right)$ de composto de lixo no decorrer das épocas, em dias após a sua aplicaçào.

\begin{tabular}{ccccc}
\hline Doses & \multicolumn{5}{c}{ Épocas, dias } \\
\cline { 2 - 5 } $\mathrm{CL}$ & 303 & 334 & 365 & 395 \\
\hline 0 & 11,46 & 11,11 & 11,72 & 11,15 \\
30 & 11,03 & 11,08 & 11,34 & 10,78 \\
60 & 10,97 & 10,75 & 11,12 & 10,72 \\
90 & 10,69 & 11,72 & 10,98 & 10,45 \\
\hline
\end{tabular}

${ }^{1}$ Média de 3 repetições $\mathrm{CV}=3,51 \%$

O aumento no teor de umidade pode ser explicado pela maior quantidade de água retida no solo quando aplicou matéria orgânica (Azeredo \& Manhães, 1983) Nào houve interação CL X adubaçào (P e/ou K). 
Tabela 13. Valores médios obtidos para Umidade $\%$ Cana $^{1}$ em função da adição de doses $\left(\mathrm{t}_{\text {. ha }}{ }^{-1}\right)$ de composto de lixo no decorrer das épocas, em dias após a sua aplicação.

\begin{tabular}{ccccc}
\hline Doses & \multicolumn{4}{c}{ Épocas, dias } \\
\cline { 2 - 5 } CL & 303 & 334 & 365 & 395 \\
\hline 0 & 71,87 & 71,65 & 69,94 & 70,02 \\
30 & 71,93 & 71,54 & 70,26 & 71,37 \\
60 & 71,76 & 71,86 & 70,15 & 71,45 \\
90 & 71,74 & 71,84 & 70,68 & 71,95 \\
\hline
\end{tabular}

TMédia de 3 repetições $\mathrm{CV}=0,70 \%$

\subsubsection{Cinzas\%Cana}

Os valores obtidos de Cinzas \% Cana para as doses de CL empregadas (0, 30,60 e 90 t.ha ${ }^{-1}$ ) são apresentadas na Tabela 14, com médias oscilando entre 0,41 e 0,49 nas 4 épocas amostradas, com tendência de aumentar os valores no decorrer do tempo. $\mathrm{O}$ valor do teste $F$, mostrou ser significativo para o fator época ao nivel de $1 \%$ de probabilidade. A mesma significância ocorreu para o fator CL nas iguais dosagens como mostra a Figura 4b com o modelo ajustado: $\mathrm{Y}=0,460+0,0057 . \mathrm{X}\left(\mathrm{R}^{2}=98,55^{* *}\right)$, com tendência de aumentar o teor de cinzas na cana conforme o acréscimo de doses. Ainda houve uma interação CL X adubação $\mathrm{P}$ e/ou $\mathrm{K}$ no nivel de significância de $5 \%$ de probabilidade para o valor do teste $\mathrm{F}$; como seguem os modelos ajustados:
a) Sem adição: $Y=0,379+0,0046 . X\left(R^{2}=88,90 * *\right)$
b) Adição de P: $Y=0,361+0,0054 . X\left(R^{2}=81,85^{* *}\right)$
c) Adição de $\mathrm{K}: \mathrm{Y}=0,446+0,0058 \cdot \mathrm{X}\left(\mathrm{R}^{2}=93,32 * *\right)$
d) Adição de PK: $Y=0,439+0,0069 . X\left(R^{2}=87,63 * *\right)$

O acréscimo de Cinzas \% Cana conforme o aumento de doses de CL é explicado por este ser rico no elemento potássio (Melo et al., 1997). Berton \& Valadares (1991) mencionaram que a dose de $30 \mathrm{t}^{\text {ha }}{ }^{-1}$ adicionaria ao solo $67 \mathrm{Kg}$ de $\mathrm{K}_{2} \mathrm{O}$. 
Tabela 14. Valores médios obtidos para Cinzas \% Cana ${ }^{1}$ em função da adição de doses $\left(\right.$ t.ha $\left.{ }^{-1}\right)$ de composto de lixo no decorrer das épocas, em dias após a sua aplicação.

\begin{tabular}{ccccc}
\hline Doses & \multicolumn{3}{c}{ Épocas, dias } \\
\cline { 2 - 5 } CL & 303 & 334 & 365 & 395 \\
\hline 0 & 0,43 & 0,44 & 0,44 & 0,39 \\
30 & 0,44 & 0,45 & 0,46 & 0,41 \\
60 & 0,45 & 0,45 & 0,46 & 0,45 \\
90 & 0,47 & 0,49 & 0,49 & 0,46
\end{tabular}

'Tédia de 3 repetições $\mathrm{CV}=8,35 \%$

Além das análises tecnológicas dos colmos, pode-se analisar alguns outros aspectos ligados ao caldo. Assim verificou-se que para o caldo não houve aumento na relação AR/Cinzas pela adição de CL e sim decréscimo que passou de 1,07 (Testemunha) para $1,00\left(30 \mathrm{t}^{\mathrm{h}} \mathrm{ha}^{-1}\right), 0,95\left(60 \mathrm{t} \cdot \mathrm{ha}^{-1}\right)$ e $0,88\left(90 \mathrm{t} \cdot \mathrm{ha}^{-1}\right)$, o que proporcionaria uma tendência ao menor esgotamento dos melaços (Honig, 1968).

\subsubsection{Pureza aparente da cana}

A pureza aparente, obtida pela relação percentual entre a Pol e o Brix, constitui um dos indices mais utilizados para o julgamento da qualidade da cana-deaçúcar com vista à sua industrialização.

Para a Pureza na cana, as diferentes doses de CL empregadas são apresentadas na Tabela 15. Em termos médios os valores oscilaram entre 85,47 e 87,15 nas 4 épocas amostradas, havendo diferença significativa entre épocas ao nivel de $1 \%$ de probabilidade para o teste F. O fato da Pureza na cana aumentar no decorrer do tempo é devido à maturação da cana, onde a Pol na cana obteve valores crescentes da primeira até a última época, o mesmo ocorrendo com o Brix na cana. 
Tabela 15. Valores médios obtidos para Pureza na cana ${ }^{1}$ em função da adição de doses de composto de lixo no decorrer das épocas, em dias após a sua aplicação.

\begin{tabular}{ccccc}
\hline Doses & \multicolumn{5}{c}{ Épocas, dias } \\
\cline { 2 - 5 } $\mathrm{CL}$ & 303 & 334 & 365 & 395 \\
\hline 0 & 85,58 & 86,25 & 85,99 & 87,15 \\
30 & 86,01 & 86,66 & 85,47 & 87,09 \\
60 & 86,21 & 86,98 & 85,89 & 86,93 \\
90 & 86,13 & 86,40 & 85,47 & 86,58 \\
\hline
\end{tabular}

Média de 3 repetições $\mathrm{CV}=1,04 \%$

$\mathrm{O}$ primeiro aspecto se refere ao fato do $\mathrm{CL}$, quando aplicado isoladamente, aumentar linearmente as produtividades dos colmos frescos (Figura 5a e 5b) de açúcar, medido pela Pol (figura 5c) e pelo Açúcar Teórico Recuperável, na industrialização da cana.

\subsubsection{Açúcar Teórico Recuperável}

Este cálculo indica a quantidade de açúcar recuperável de uma dada cana. Evidentemente, são muitas as condições que fazem este dado variar.

Houve interação do CL com a adubação química, com significância ao nível de $5 \%$ de probabilidade para o teste $\mathrm{F}$. $\mathrm{O}$ fator $\mathrm{Cl}$, quando aplicado de modo geral, não obteve significância para o teste $F$.

Verificou-se pelos valores médios de ATR na cana açúcar dos tratamentos que não houve redução do teor de açúcar nos colmos pela adição de $\mathrm{CL}$, e combinados com fertilizantes (Tabelas 15 e 16). Tendo sido ajustados os seguintes modelos em resposta à adição de $\mathrm{CL}$, combinados ou não com fertilizante (K ou $\mathrm{PK}$ ):

a) Sem adubo: $\mathrm{Y}=119,4+0,027 . \mathrm{X}\left(\mathrm{R}^{2}=86,60 * *\right)$

b) Adição de $\mathrm{K}: \mathrm{Y}=120,9+0,10 . X-0,0013 \cdot \mathrm{X}^{2}\left(\mathrm{R}^{2}=99,94^{* *}\right)$

c) Adição de PK: $\mathrm{Y}=118,2+0,045 . \mathrm{X}\left(\mathrm{R}^{2}=75,91^{* *}\right)$ 
Tabela 16. Efeitos da adição combinada de doses de composto de lixo e de suplementação P, K e PK na concentração de Açúcar Teórico Recuperável (ATR) em cana-de-açúcar, expresso em $\mathrm{Kg} / \mathrm{t}$. (média de 4 meses no decorrer de 1997).

\begin{tabular}{|c|c|c|c|c|c|c|}
\hline \multirow{2}{*}{\multicolumn{2}{|c|}{ Doses de CL, tha ${ }^{-1}$}} & \multicolumn{4}{|c|}{ Fertilizantes Químicos } & \multirow{2}{*}{$\begin{array}{l}\text { Médias de } \\
\text { doses CL }\end{array}$} \\
\hline & & $\begin{array}{c}\text { Sem adição } \\
(00)\end{array}$ & $\mathrm{P}$ & $\mathrm{K}$ & $\mathrm{PK}$ & \\
\hline \multicolumn{2}{|c|}{00} & $119,0 \quad b$ & $121,9 \mathrm{ab}$ & $120,9 \mathrm{~b}$ & $\mathrm{I} 18,0 \mathrm{~b}$ & $120,0 \mathrm{a}$ \\
\hline \multicolumn{2}{|c|}{30} & $120,2 \mathrm{ab}$ & $121,5 \mathrm{ab}$ & $122,8 \mathrm{a}$ & $120,3 \mathrm{ab}$ & $121,2 \mathrm{a}$ \\
\hline \multicolumn{2}{|c|}{60} & $120,9 \mathrm{ab}$ & 124,4 a & $122,3 \mathrm{ab}$ & $119,5 \mathrm{ab}$ & $121,8 \mathrm{a}$ \\
\hline \multicolumn{2}{|c|}{90} & 121,8 a & $120,6 \mathrm{~b}$ & $119,6 \mathrm{a}$ & $122,9 \mathrm{a}$ & $121,2 \mathrm{a}$ \\
\hline \multicolumn{2}{|c|}{ Média de Fertiliz. } & $120,5 \quad b$ & 122,1 a & $121,4 \mathrm{ab}$ & $121,2 \mathrm{ab}$ & 121,1 \\
\hline Causas de & $\mathrm{Cl}$ & \multicolumn{5}{|c|}{$*$} \\
\hline Variação & Química & \multicolumn{4}{|c|}{$*$} & \\
\hline (Valor F) & CLXQ & \multicolumn{4}{|c|}{$*$} & \\
\hline \multicolumn{2}{|c|}{$\mathrm{CV} \%$} & \multicolumn{4}{|c|}{2,96} & \\
\hline
\end{tabular}

$\mathrm{CL}=$ composto de lixo urbano; ${ }^{*} \mathrm{e}^{* *}=$ significativo a $5 \%$ e $1 \%$ de probabilidade no teste F.

\subsection{Efeitos da aplicação de CL no número e peso dos colmos (t.ha $\left.{ }^{-1}\right)$ e de açúcar total ( $\mathrm{t}$ Pol.ha ${ }^{-1}$ ) e recuperável (TAH)}

Houve um aumento linear com a aplicação de CL sobre o número e a produção de colmos (Tabelas 17 e 18, Figuras 5a e 5b). Entretanto deve ser salientado que o único modelo efetivamente ajustado para avaliar os efeitos das doses de CL sobre o número de colmos de cana por hectare foi $\mathrm{Y}=76589+56,097 . \mathrm{X}\left(\mathrm{R}^{2}=75,12 * *\right)$, que utilizou-se de médias gerais de cada nivel do fator composto (sem considerar qualquer interação com nutrientes $\mathrm{P}, \mathrm{K}$ e $\mathrm{PK}$ ) 

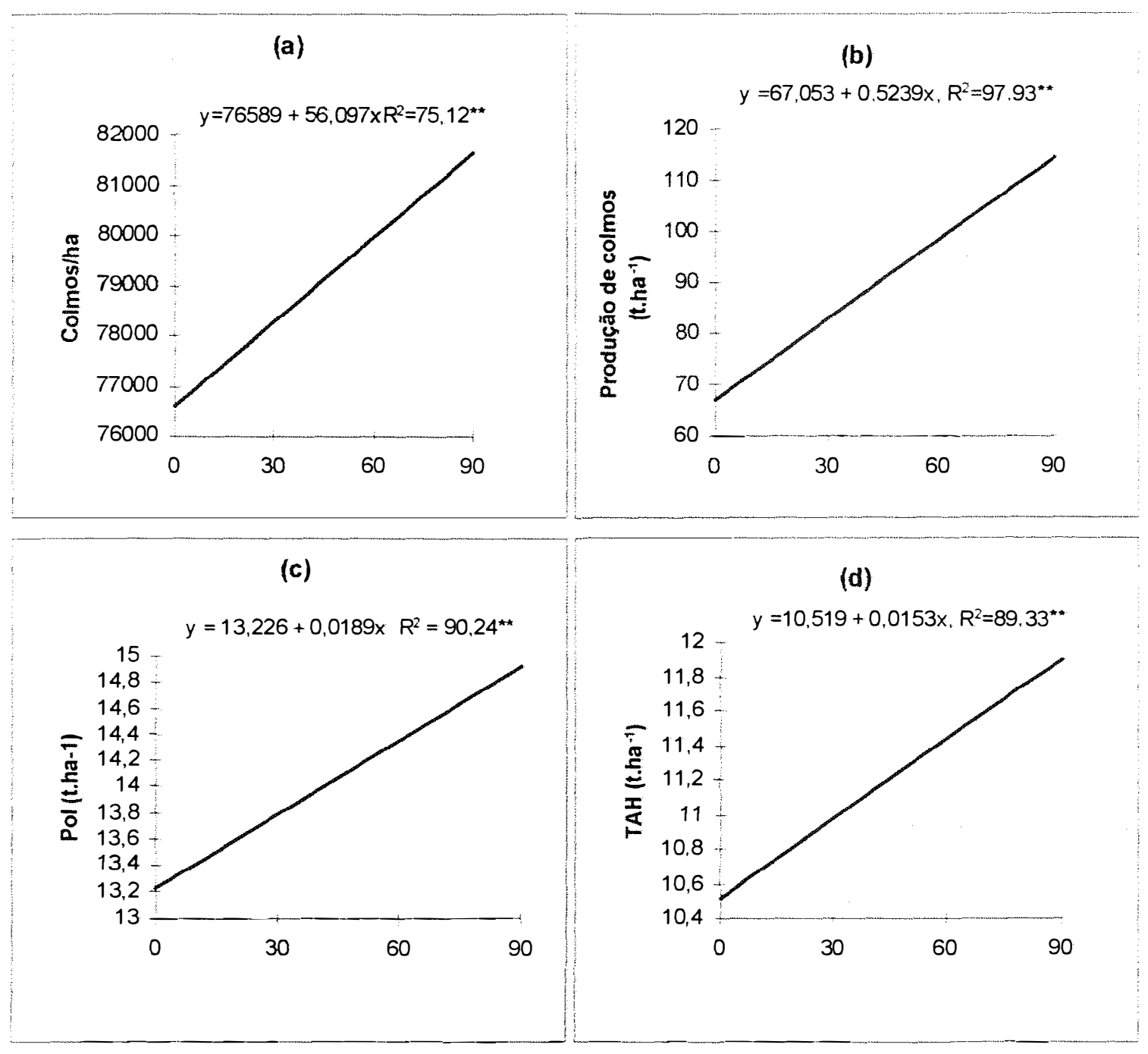

Composto de Lixo Urbano, $\mathrm{t} \mathrm{ha}^{-\mathrm{J}}$

Figura 5. Influência da aplicação de composto de lixo ao solo sobre a quantidade (a) e a produtividade de colmos (b) e nas produções de Pol (c) e Açúcar teórico recuperável $(\mathrm{d})$ por hectare. *- significativo a $5 \%$ de probabilidade no teste $\mathrm{F}$; ** significativo a $1 \%$ de probabilidade no teste $\mathrm{F}$. 
Tabela 17. Efeitos da adição combinada de doses de composto de lixo e de suplementação $\mathrm{P}, \mathrm{K}$ e PK no número de colmos de cana-de-açúcar por hectare (média de 6 meses finais no decorrer de 1997).

\begin{tabular}{|c|c|c|c|c|c|c|}
\hline \multicolumn{2}{|c|}{ Doses de CL, t.ha ${ }^{-1}$} & \multicolumn{4}{|c|}{ Fertilizantes Químicos } & \multirow{2}{*}{$\begin{array}{l}\text { Médias de } \\
\text { doses CL }\end{array}$} \\
\hline & & $\begin{array}{c}\text { Sem adição } \\
(00)\end{array}$ & $\mathrm{P}$ & $\mathrm{K}$ & PK & \\
\hline \multicolumn{2}{|c|}{00} & $71593 \mathrm{a}$ & $76346 a$ & $75636 a$ & $78982 \mathrm{a}$ & $76589 \mathrm{a}$ \\
\hline \multicolumn{2}{|c|}{30} & $79326 \mathrm{a}$ & $81726 a$ & $80491 \mathrm{a}$ & $75117 \mathrm{a}$ & $7827 ! \mathrm{ab}$ \\
\hline \multicolumn{2}{|c|}{60} & $78985 \mathrm{a}$ & $79722 \mathrm{a}$ & $79220 \mathrm{a}$ & $86880 \mathrm{a}$ & $81637 \mathrm{~b}$ \\
\hline \multicolumn{2}{|c|}{90} & 82403 a & $80352 \mathrm{a}$ & $76901 \mathrm{a}$ & $82361 \mathrm{a}$ & $79113 \mathrm{~b}$ \\
\hline \multicolumn{2}{|c|}{ Média de Fertiliz. } & $78077 \mathrm{a}$ & $79545 \mathrm{a}$ & $77994 \mathrm{a}$ & $80835 \mathrm{a}$ & \\
\hline Causas de & $\mathrm{CL}$ & \multicolumn{5}{|c|}{$* *$} \\
\hline Variação & Quimica & \multicolumn{5}{|c|}{ NS } \\
\hline (Valor F) & CLXQ & \multicolumn{5}{|c|}{ NS } \\
\hline \multicolumn{2}{|c|}{$\mathrm{CV} \%$} & \multicolumn{5}{|c|}{11,02} \\
\hline
\end{tabular}

$\mathrm{CL}=$ composto de lixo urbano; ${ }^{*} \mathrm{e}^{* *}=$ significativo a $5 \%$ e $1 \%$ de probabilidade no teste $\mathrm{F}$.

Conforme houve acréscimo das doses de composto de lixo, de modo geral, o número de colmos por área aumentou, obtendo significância ao nível de $1 \%$ de probabilidade no teste $\mathrm{F}$. O número de colmos por área se correlacionou com o pH do solo $\left(0,20^{*}\right)$ e o $\operatorname{Mg}\left(0,36^{* *}\right)$, devido a capacidade do composto em alterar as propriedades químicas do solo, como já mencionados por alguns autores (Messias \& Moraes, 1992; Hernando et al., 1989)

Resultado semelhante ao encontrado na pesquisa foi obtido por Alleoni et al. (1995), aplicando torta de filtro como fonte de materia orgânica para o solo, na dose de 15 t. ha ${ }^{-1}$ de matéria seca, aumentando o número de perfilhos em $53 \%$.

As doses de $\mathrm{CL}$ aumentou o número de colmos por hectare em relação à 


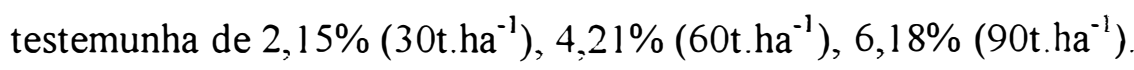

Tabela 18. Efeitos da adição combinada de doses de composto de lixo e de suplementação PK na produtividade de colmos $(\mathrm{TCH})$ de cana-de-açúcar em t.ha ${ }^{-1}$ na colheita do experimento (meados de outubro/1997).

\begin{tabular}{|c|c|c|c|c|c|c|}
\hline \multirow{2}{*}{\multicolumn{2}{|c|}{ Doses de CL, th ha ${ }^{-1}$}} & \multicolumn{4}{|c|}{ Fertilizantes Quimicos } & \multirow{2}{*}{$\begin{array}{l}\text { Médias de } \\
\text { doses } \mathrm{Cl}\end{array}$} \\
\hline & & $\begin{array}{c}\text { Sem adição } \\
(00)\end{array}$ & $P$ & $\mathrm{~K}$ & PK & \\
\hline \multicolumn{2}{|c|}{00} & $70 \quad b$ & $88 \mathrm{a}$ & $83 \mathrm{a}$ & $121 \mathrm{a}$ & 90,7 a \\
\hline \multicolumn{2}{|c|}{30} & $78 \mathrm{ab}$ & $97 \mathrm{a}$ & $115 \mathrm{a}$ & $103 \mathrm{a}$ & $98,3 \mathrm{ab}$ \\
\hline \multicolumn{2}{|c|}{60} & $98 \mathrm{a}$ & $112 \mathrm{a}$ & $95 \mathrm{a}$ & $113 \mathrm{a}$ & $104,5 \mathrm{~b}$ \\
\hline \multicolumn{2}{|c|}{90} & $103 \mathrm{a}$ & $92 \mathrm{a}$ & $97 \mathrm{a}$ & $112 \mathrm{a}$ & $101,0 \mathrm{ab}$ \\
\hline \multicolumn{2}{|c|}{ Média de Fertiliz. } & $87 \mathrm{~b}$ & $97 \mathrm{ab}$ & $98 \mathrm{ab}$ & $112 \mathrm{a}$ & 98,6 \\
\hline Causas de & $\mathrm{CL}$ & \multicolumn{4}{|c|}{$* *$} & \\
\hline Variação & Quimica & \multicolumn{4}{|c|}{ * } & \\
\hline (Valor F) & CLXQ & \multicolumn{4}{|c|}{ NS } & \\
\hline \multicolumn{2}{|c|}{$\mathrm{CV} \%$} & \multicolumn{4}{|c|}{17,19} & \\
\hline
\end{tabular}

$\mathrm{CL}=$ composto de lixo urbano; ${ }^{*} \mathrm{e}^{* *}=$ significativo a $5 \%$ e $1 \%$ de probabilidade no teste F.

A produção de colmos por hectare $(\mathrm{TCH})$ é apresentada na Tabela 18 , onde o $\mathrm{CL}$ não interagiu com a adubação $\mathrm{P}, \mathrm{K}$ e $\mathrm{PK}$. Mas o fator $\mathrm{CL}$, quando aplicado isoladamente obteve significância ao nivel de $1 \%$ de probabilidade no teste $\mathrm{F}$ e se correlacionou com algumas caracteristicas quimicas do solo $\left(\mathrm{pH}\left(0,44^{* *}\right)\right.$; $\mathrm{P}\left(0,45^{* *}\right)$; $\mathrm{V} \%\left(0,37^{* *}\right)$; CTC $\left(0,26^{* *}\right) ; \mathrm{Mg}\left(0,39^{* *}\right) ; \mathrm{H}+\mathrm{Al}\left(-0,26^{*}\right)$. A produtividade aumentou linearmente, da menor para a maior dose aplicada a o solo, conforme mostra a Figura 5 b.

Comparando-se as doses de CL aplicadas ao solo com a testemunha $\left(0\right.$ t.ha $\left.{ }^{-1}\right)$, houve um acréscimo de 18,98\% $\left(30\right.$ t.ha $\left.^{-1}\right), 31,91 \%\left(60\right.$ t.ha $\left.^{-1}\right)$, e $41,28 \%$ 
(90t.ha-1) no peso de colmos em toneladas por hectare (Figura 5b).

A produtividade agricola foi maior quando combinou-se $\mathrm{CL}+\mathrm{PK}$ (Tabela 18).. Todavia, o modelo efetivamente ajustado para avaliar os efeitos das doses de composto de lixo sobre a produtividade foi $\mathrm{Y}=67,05+0,53 . \mathrm{X}\left(\mathrm{R}^{2}=97,09^{* *}\right)$, que utilizou-se de médias de cada nivel do fator $\mathrm{CL}$.

Esses resultados, tanto para o número de colmos como para o peso de colmos, refletem um provável beneficio da adição da matéria orgânica na forma de CL sobre a produção da cana-de-açúcar como já observara alguns autores (Hernando et al. (1989); Messias \& Moraes (1992); Moraes \& Selbach (1991); Mazur et al. (1983); Collier et al. (1992).

A produtividade em açúcar Pol tha ${ }^{-1}$, obteve significância ao nivel de $1 \%$ de probabilidade no teste $\mathrm{F}$. O CL quando aplicado para médias gerais aumentou linearmente a Pol, conforme suas doses crescentes $\left(0,30,60\right.$ e 90t.ha $\left.{ }^{-1}\right)$ com os valores correspondidos em 13,23, 13,79, 14,36 e 14,93t. ha ${ }^{-1}$, respectivamente (Figura 5c). Efeitos semelhantes Castro \& Godoy (1979) obtiveram quando aplicaram 3 tha ${ }^{-1}$ de matéria orgânica, na forma de torta de filtro (seca) + NPK resultando em um aumento de produtividade da Pol de 2,8t.ha ${ }^{-1}$.

Houve interação entre $C L$ x adubação química (PK), obtendo significância ao nivel de $5 \%$ de probabilidade no teste $\mathrm{F}$ (Tabela 19), com os modelos ajustados para a produtividade em açúcar Pol t.ha ${ }^{-1}$ :

a) Sem adubo: $\mathrm{Y}=11,71+0,032 \cdot \mathrm{X}\left(\mathrm{R}^{2}=79,28^{* *}\right)$

b) Adição de PK: $\mathrm{Y}=13,18+0,042 \cdot \mathrm{X}\left(\mathrm{R}^{2}=89,65^{* *}\right)$

c) Média geral: $Y=13,22+0,019 . X\left(R^{2}=90,24^{* *}\right)$

Já os modelos ajustados para a produtividade do Açúcar Teórico Recuperável (TAH) nos colmos de cana-de-açúcar, expressos em tha ${ }^{-1}$, obteve níveis de significância ao nivel de $1 \%$ de probabilidade no teste $\mathrm{F}$, quando aplicado com a adubação química PK (Tabela 20) e também para a aplicação isolada do CL.

Quando o CL foi aplicado de modo geral os valores para TAH aumentaram linearmente, conforme as doses crescentes $\left(0,30,60\right.$ e 90 t.ha $\left.^{-1}\right)$ obtendo as 
respectivas produtividades: $10,52,10,98,11,44$ e 11,90 tha $^{-1}$ (Figura 5d).

Tabela 19. Efeitos da adição combinada de doses de composto de lixo e de suplementação $\mathrm{P}, \mathrm{K}$ e PK na produtividade em açúcar, em toneladas de Pol por hectare.

\begin{tabular}{|c|c|c|c|c|c|c|}
\hline \multirow{2}{*}{\multicolumn{2}{|c|}{ Doses de CL, t.ha ${ }^{-1}$}} & \multicolumn{4}{|c|}{ Fertilizantes Químicos } & \multirow{2}{*}{$\begin{array}{c}\text { Médias de } \\
\text { doses CL }\end{array}$} \\
\hline & & $\begin{array}{c}\text { Sem adição } \\
(00)\end{array}$ & $\mathrm{P}$ & $\mathrm{K}$ & PK & \\
\hline \multicolumn{2}{|c|}{00} & $11,89 \mathrm{a}$ & $14,11 \mathrm{a}$ & $13,20 \mathrm{a}$ & $13,45 \mathrm{~b}$ & $13,16 \mathrm{~b}$ \\
\hline \multicolumn{2}{|c|}{30} & $12,00 \mathrm{a}$ & $14,08 \mathrm{a}$ & $14,10 a$ & $13,58 \mathrm{~b}$ & $13,44 \mathrm{ab}$ \\
\hline \multicolumn{2}{|c|}{60} & $14,44 \mathrm{a}$ & $14,94 \mathrm{a}$ & $13,42 \mathrm{a}$ & $16,00 \mathrm{a}$ & $14,70 \mathrm{a}$ \\
\hline \multicolumn{2}{|c|}{90} & $14,30 \mathrm{a}$ & $14,05 \mathrm{a}$ & 13,69 a & 16,92 a & $14,47 \mathrm{a}$ \\
\hline \multicolumn{2}{|c|}{ Média de Fertiliz. } & $13,15 a$ & $14,30 \mathrm{ab}$ & $13,80 \mathrm{ab}$ & $15,05 \mathrm{a}$ & 14,08 \\
\hline Causa de & $\mathrm{CL}$ & \multicolumn{5}{|c|}{$* *$} \\
\hline Variação & Química & \multicolumn{5}{|c|}{$* *$} \\
\hline (Valor F) & CLXQ & \multicolumn{5}{|c|}{ * } \\
\hline \multicolumn{2}{|c|}{$\mathrm{CV} \%$} & \multicolumn{5}{|c|}{17,82} \\
\hline
\end{tabular}

$\mathrm{CL}=$ composto de lixo urbano; ${ }^{*} \mathrm{e}^{* *}=$ significativo a $5 \%$ e $1 \%$ de probabilidade no teste F. 
Tabela 20. Efeitos da adição combinada de doses de composto de lixo e de suplementação PK na produtividade de Açúcar Teorico Recuperável por hectare (TAH)

\begin{tabular}{|c|c|c|c|c|c|c|}
\hline \multicolumn{2}{|c|}{ Doses de CL, $\mathrm{t}^{\mathrm{ha}}{ }^{-1}$} & \multicolumn{4}{|c|}{ Fertilizantes Quimicos } & \multirow{2}{*}{$\begin{array}{l}\text { Médias de } \\
\text { doses CL }\end{array}$} \\
\hline & & $\begin{array}{c}\text { Sem adição } \\
(00)\end{array}$ & $P$ & $\mathrm{~K}$ & PK & \\
\hline \multicolumn{2}{|c|}{00} & $9,43 \mathrm{a}$ & $11,22 \mathrm{a}$ & $10,50 \mathrm{a}$ & $10,76 \mathrm{a}$ & $10,48 \mathrm{~b}$ \\
\hline \multicolumn{2}{|c|}{30} & $9,54 \mathrm{a}$ & $11,24 \mathrm{a}$ & $11,51 \mathrm{a}$ & $10,87 \mathrm{a}$ & $10,79 \mathrm{ab}$ \\
\hline \multicolumn{2}{|c|}{60} & $11,48 \mathrm{~b}$ & $11,97 \mathrm{a}$ & $10,75 \mathrm{a}$ & $12,74 \mathrm{~b}$ & $11,74 \mathrm{a}$ \\
\hline \multicolumn{2}{|c|}{90} & $11,32 \mathrm{~b}$ & $11,18 \mathrm{a}$ & $10,87 \mathrm{a}$ & $13,52 \mathrm{~b}$ & $11,72 \mathrm{a}$ \\
\hline \multicolumn{2}{|c|}{ Média de Fertiliz. } & $10,46 \mathrm{~b}$ & $11,40 \mathrm{ab}$ & $11,00 \mathrm{ab}$ & $11,97 \mathrm{~b}$ & 11,18 \\
\hline Causas de & $\mathrm{CL}$ & \multicolumn{4}{|c|}{ ** } & \\
\hline Variação & Quimica & \multicolumn{4}{|c|}{$* *$} & \\
\hline (Valor F) & CLXQ & \multicolumn{4}{|c|}{$*$} & \\
\hline \multicolumn{2}{|c|}{$\mathrm{CV} \%$} & \multicolumn{4}{|c|}{18,02} & \\
\hline
\end{tabular}

$\mathrm{CL}=$ composto de lixo urbano; ${ }^{*} \mathrm{e}^{* *}=$ significativo a $5 \%$ e $1 \%$ de probabilidade no teste F.

Já os modelos ajustados para a produtividade de Açúcar Teórico Recuperável (TAH) nos colmos de cana-de-açúcar por hectare, em resposta à adição de CL, acrescido com a adubação química PK (Tabela 20), as quais apresentam as seguintes equações:
a) Sem adubo: $\mathrm{Y}=9,30+0,015 . \mathrm{X}\left(\mathrm{R}^{2}=89,22 * *\right)$
b) Adição de PK: $\mathrm{Y}=10,45+0,026 \cdot \mathrm{X}^{2}\left(\mathrm{R}^{2}=79,65^{* *}\right)$
c) Média geral: $\mathrm{Y}=10,52+0,015 \cdot \mathrm{X}\left(\mathrm{R}^{2}=89,54^{* *}\right)$ 


\subsection{Efeitos da aplicação de $\mathrm{CL}$ nos teores de $\mathrm{P}$ e de $\mathrm{K}$ no caldo}

O fósforo presente no caldo é muito importante para a adequada clarificação quando da produção do açúcar, e niveis de fosfato superiores a $150 \mathrm{mg} . \mathrm{L}^{-}$ $\mathrm{P}_{2} \mathrm{O}_{5}{ }^{1}$ são considerados ideais (Delgado e Cesar, 1984).

Deve ser observado que o teor de $\mathrm{P}$ no caldo aumentou da testemunha à última dose aplicada de CL $\left(90 \mathrm{t}^{\mathrm{h}} \mathrm{ha}^{-1}\right)$ como mostra a Figura 6a. O fator épocas não obteve valor significativo para o teste F (Tabela 21 ).

Tabela 21 . Teores de fósforo no caldo $\left(\mathrm{mg}_{\mathrm{L}} \mathrm{L}^{-1}\right)$ em função das doses de composto de lixo no decorrer das épocas.

\begin{tabular}{|c|c|c|c|c|}
\hline \multirow[t]{3}{*}{ Tratamentos } & \multicolumn{4}{|c|}{ Epocas } \\
\hline & 303 dap & 334 dap & 365 dap & 395 dap \\
\hline & \multicolumn{3}{|c|}{$\mathrm{P}\left(\mathrm{mg} \cdot \mathrm{L}^{-1}\right)$} & \\
\hline $\mathrm{T}$ & 221 & 161 & 169 & 146 \\
\hline $\mathrm{P}$ & 173 & 126 & 152 & 149 \\
\hline 30 t. ha $^{-1}$ & 236 & 117 & 179 & 168 \\
\hline 30 t. ha ${ }^{-1}+\mathrm{P}$ & 222 & 179 & 197 & 174 \\
\hline 60 t. ha ${ }^{-1}$ & 259 & 172 & 212 & 179 \\
\hline 60 t. ha ${ }^{-1}+\mathrm{P}$ & 217 & 170 & 180 & 165 \\
\hline 90 t. ha ${ }^{-1}$ & 248 & 184 & 200 & 161 \\
\hline 90 t. ha $^{-1}+\mathrm{P}$ & 226 & 172 & 203 & 180 \\
\hline
\end{tabular}

\footnotetext{
${ }^{1}$ Média de 3 repetições, $\mathrm{CV}=11.01 \%$
} 

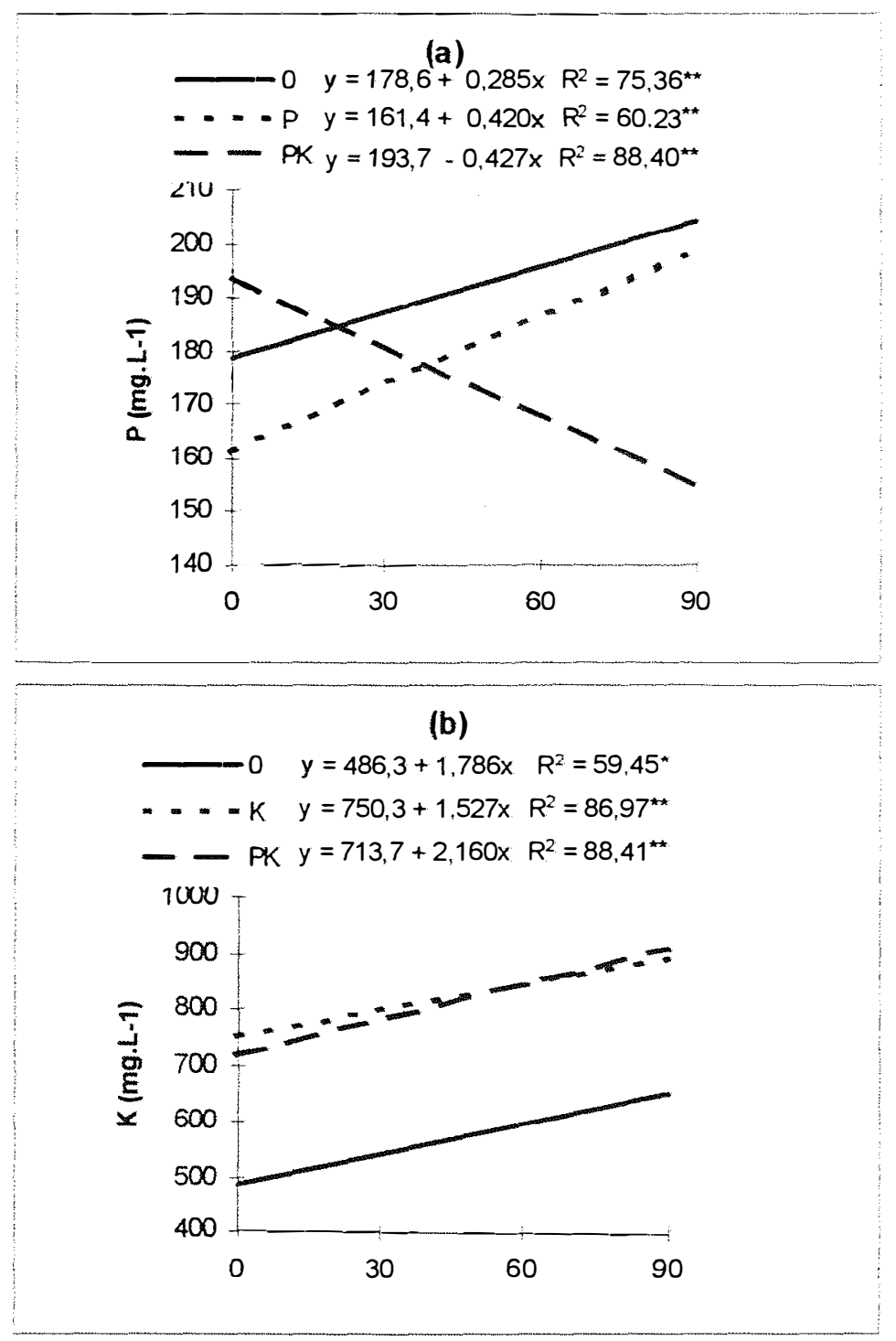

Composto de Lixo Urbano, $\mathrm{t}_{\text {ha }}{ }^{-1}$

Figura 6. Influência da aplicação de doses de composto de lixo, suplementados ou não com $\mathrm{P}$ e/ou $\mathrm{K}$ nos teores de fósforo (a) e de potássio (b) no caldo de cana-deacúcar. *- significativo a $5 \%$ de probabilidade no teste $\mathrm{F}$; **- significativo a $1 \%$ de probabilidade no teste $\mathrm{F}$. 
Os teores de fósforo do caldo estão dentro das necessidades exigidas para fermentação alco,olica(Amorim, 1985) e na clarificação para o açúcar (Delgado \& Cesar, 1984).

$\mathrm{O}$ teor de fósforo no caldo foi influenciado pelos fatores $\mathrm{CL}$ e fertilizantes fosfatados e como nota-se na Figura 6a, tendo os seguintes modelos para o $\mathrm{P}$ no caldo ajustados em resposta à adição ao $\mathrm{CL}$ :
a) Sem adubo: $\mathrm{Y}=178,6+0,29 \cdot \mathrm{X}\left(\mathrm{R}^{2}=75,36^{* *}\right)$
b) Adição de $\mathrm{P}$ : $\mathrm{Y}=161,4+0,42 \cdot \mathrm{X}\left(\mathrm{R}^{2}=60,23^{* *}\right)$
c) Adição de PK: $\mathrm{Y}=193,7-0,43 \cdot \mathrm{X}\left(\mathrm{R}^{2}=88,40^{* *}\right)$

A aplicação isolada do $\mathrm{CL}$ foi significativa para o teste $\mathrm{F}$ no nível de $1 \%$ de probabilidade e elevou linearmente o teor de fósforo no caldo da menor para a maior dose aplicada $\left(0,30,60\right.$ e 90t. ha $\left.^{-1}\right)$ obtendo respectivamente os valores de 178,6, 187,2, 195,7 e $204,3 \mathrm{mg} \cdot \mathrm{L}^{-1}$. Tal fato pode ser explicado devido o $\mathrm{CL}$ possuir teores de fósforo mais altos do que a maioria dos solos agricolas e ficarem disponiveis em $15 \%$ do seu total para as plantas (DeHaan, 1981).

Considerando que o teor de $\mathrm{P}_{2} \mathrm{O}_{5}$ no $\mathrm{CL}$ aplicado é de $2,5 \mathrm{~g} \cdot \mathrm{Kg}^{-1}$, houve portanto, um acréscimo de $75 \mathrm{~kg} \cdot$ ha $^{-1}$ do fosfato para cada $30 \mathrm{t} \mathrm{de} \mathrm{CL}$, no solo.

$\mathrm{O} C L$ quando suplementado com adubação fosiatada $\left(120 \mathrm{~kg} \cdot \mathrm{ha}^{-1}\right.$ de $\left.\mathrm{P}_{2} \mathrm{O}_{5}\right)$ elevou linearmente o teor de fósforo no caldo a partir da menor para a maior dose aplicada obtendo os teores respectivos de $161,4,173,9,186,5$ e 199, $1 \mathrm{mg} . \mathrm{L}^{-1}$, mas com teores menores do que quando aplicado isoladamente.

Quando o CL aplicado ao solo somado da adubação PK (120Kg.ha ${ }^{-1}$ de $\mathrm{KCl}$ ), o teor de fósforo no caldo decresceu linearmente conforme as doses crescentes, obtendo valores respectivos de 193,7, 180,9, 168,1 e 155,3mg. $\mathrm{L}^{-1}$.

Já a questão do teor de $\mathrm{K}$ no caldo dos colmos foi influenciado da adição do composto de lixo, do fertilizante potássico e pela sua interação, ao nivel de significância de $1 \%$ de probabilidade pelo Teste $F$, como evidencia-se na Figura $6 \mathrm{~b}$. Os modelos para o $\mathrm{K}$ no caldo ajustados em resposta à adição de composto de lixo foram os seguintes: 

a) Sem adubo: $\mathrm{Y}=486,3+1,786 . \mathrm{X}\left(\mathrm{R}^{2}=59,45^{*}\right)$
b) Adição de $\mathrm{K}: \mathrm{Y}=750,3+1,527 \cdot \mathrm{X}\left(\mathrm{R}^{2}=86,97^{* *}\right)$
c) Adição de PK: $\mathrm{Y}=713,7+2,160 . \mathrm{X}\left(\mathrm{R}^{2}=88,41^{* *}\right)$

Tabela 22. Teores de potássio no caldo $\left(\mathrm{mg} . \mathrm{L}^{-1}\right)$ em função das doses de composto de lixo no decorrer das épocas.

\begin{tabular}{|c|c|c|c|c|}
\hline \multirow[t]{3}{*}{ Tratamentos } & \multicolumn{4}{|c|}{ Épocas } \\
\hline & \multicolumn{3}{|c|}{$\mathrm{K}\left(\mathrm{mg} \cdot \mathrm{L}^{-1}\right)$} & \multirow[b]{2}{*}{395 dap } \\
\hline & 303 dap & 334 dap & 365 dap & \\
\hline$T$ & 636 & 656 & 624 & 546 \\
\hline $\mathrm{P}$ & 720 & 803 & 816 & 720 \\
\hline $30 \mathrm{t} \cdot \mathrm{ha}^{-1}$ & 501 & 553 & 611 & 475 \\
\hline 30t.ha ${ }^{-1}+K$ & 720 & 765 & 778 & 797 \\
\hline $60 \mathrm{t} \cdot \mathrm{ha}^{-1}$ & 495 & 533 & 520 & 514 \\
\hline 60 t. ha $^{-1}+\mathrm{K}$ & 829 & 823 & 861 & 932 \\
\hline $90 \mathrm{t} \cdot \mathrm{ha}^{-1}$ & 739 & 701 & 694 & 668 \\
\hline 90t.ha ${ }^{-1}+\mathrm{K}$ & 842 & 861 & 932 & 945 \\
\hline
\end{tabular}

${ }^{1}$ Média de 3 repetições $\mathrm{CV}=15,64 \%$

Para a industrialização do açúcar o $\mathrm{K}$ é elemento negativo por ser considerado melacigênico e positivo para a fermentação quando estes valores permanecem na faixa de 700 a $1.200 \mathrm{mg} . \mathrm{L}^{-1}$ de $\mathrm{K}^{+}$.

A aplicação isolada do $\mathrm{CL}$ elevou linearmente os teores de $\mathrm{K}^{*}$ no caldo, da menor dose para a maior dose $\left(0,30,60\right.$ e 90 t.ha $\left.^{-1}\right)$ aplicada ao solo respectivamente em $486,540,594$ e $647 \mathrm{mg} . \mathrm{L}^{-1}$.

O CL por ser rico em potássio, a aplicação de $30 t \cdot \mathrm{ha}^{-1}$ do composto empregado no presente experimento, forneceu ao solo $123 \mathrm{Kg}_{\mathrm{gha}}{ }^{-1}$ de $\mathrm{K}_{2} \mathrm{O}$, apresentando este um teor acima dos $67 \mathrm{Kg}$ de $\mathrm{K}_{2} \mathrm{O}$ como mencionado por Berton \& Valadares (1991) 
Quando o CL foi suplementado com potássio $(\mathrm{KCl})$, elevou linearmente os teores de $\mathrm{K}^{-}$no caldo, em valores de $750,796,842$ e $888 \mathrm{mg}^{-\mathrm{L}^{-1}}$, respectivamente.

Resultado semelhante foi obtido quando se adicionou ao solo o $\mathrm{CL}+$ adubação PK, elevando linearmente os teores de $\mathrm{K}$ " do caldo dos colmos, aumentando os valores conforme o aumento das doses do composto em $714,779,843$ e $908 \mathrm{mg}$. L ${ }^{-1}$.

A Tabela 23 contém os resultados das correlações entre parâmetros agrotecnológicos e as variáveis do solo.

Tabela 23. Valor de correlação entre as produtividades da cana-planta, expressa em colmos colhidos aos 369 dap, em relação aos testes de algumas espécies quimicas do solo, amostrados aos 120 dap.

\begin{tabular}{|c|c|}
\hline Parâmetros agrotecnológicos & Variáveis do solo correlacionadas (r) \\
\hline Peso de colmos, em t.ha ${ }^{-1}$ & $\begin{array}{l}\text { pH }\left(0,44^{* *}\right), \mathrm{P}\left(0,45^{* *}\right), \mathrm{Ca}\left(0,39^{* *}\right), \mathrm{V} \%\left(0,37^{* *}\right), \\
\mathrm{CTC}\left(0,26^{*}\right), \operatorname{Mg}\left(0,39^{* *}\right), \mathrm{H}+\mathrm{Al}\left(-0,26^{*}\right), \mathrm{Na}\left(0,31^{*}\right)\end{array}$ \\
\hline$N^{0}$ colmos, por hectare & $\mathrm{pH}\left(0,29^{*}\right), \operatorname{Mg}\left(0,36^{*}\right)$ \\
\hline Tpol/ha, em t.ha ${ }^{-1}$ & Não houve correlação \\
\hline $\mathrm{TAH}$, em t. ha ${ }^{-1}$ & $\begin{array}{l}\mathrm{pH}\left(0,42^{* *}\right), \mathrm{P}\left(0,44^{* *}\right), \mathrm{Ca}\left(0,36^{*}\right), \mathrm{V} \%\left(0,34^{*}\right), \mathrm{Mg} \\
\left(0,39^{* *}\right)\end{array}$ \\
\hline ATR, em tha ${ }^{-1}$ & $\begin{array}{l}\mathrm{pH}\left(0,39^{* *}\right), \mathrm{P}\left(0,39^{* *}\right), \mathrm{Ca}\left(0,34^{*}\right), \mathrm{V} \%\left(0,31^{*}\right), \mathrm{Mg} \\
\left(0,38^{* *}\right)\end{array}$ \\
\hline $\mathrm{K}_{2} \mathrm{O}$ no caldo, em $\mathrm{mg} \cdot \mathrm{L}^{-1}$ & $\mathrm{P}\left(0,40^{* *}\right), \mathrm{K}\left(0,30^{*}\right), \mathrm{CTC}\left(0,28^{*}\right)$ \\
\hline $\mathrm{P}_{2} \mathrm{O}_{5}$ no caldo, em $\mathrm{mg} \cdot \mathrm{L}^{-1}$ & $\mathrm{P}\left(0,47^{* *}\right), \mathrm{K}\left(0,30^{*}\right), \mathrm{CTC}\left(0,34^{*}\right)$ \\
\hline
\end{tabular}

${ }^{*} \mathrm{e}^{* *}=$ significativos a 5 e $1 \%$ no teste $\mathrm{F}$. 


\section{CONCLUSÃO}

Da análise estatística dos dados e de sua discussão chegou-se as principais conclusões:

1. Não houve atraso na maturação da cana-de-açúcar pela adição de composto de lixo, pois não afetou os parâmetros que julgam a qualidade tecnológica da cana-de-açúcar para sua industrialização, quando estudado dentro de épocas, quais sejam: Brix, pol, açúcares redutores, pureza aparente. Entretanto, a resposta ótima da cultura em acumulação de açúcar dos colmos acorreu na combinação do composto com fertilizante (P ou K).

2. O CL aplicado ao solo neutralizou a acidez potencial totalmente, provocando ainda aumentos no seu $\mathrm{pH}$, na CTC, na soma e na saturação por bases.

3. A adição de $\mathrm{CL}$ elevou linearmente os teores de $\mathrm{P}$ e $\mathrm{K}$ no solo que promoveu aumentos proporcionais de seus teores no caldo. Todavia os teores de $\mathrm{P}$ e $\mathrm{K}$ no caldo foram também influenciados pela adição de fertilizantes fosfatado e potássico, respectivamente.

4. A aplicação de composto de lixo proporcionou aumento linear na resposta em produtividade de colmos e açúcar por hectare. 


\section{REFERÊNCIAS BIBLIOGRÁFICAS}

AIRAN, D. S.;EBELL, J. H. Resource recovery through composting - a sleeping giant. In: NATIONAL WASTE PROCESS/ CONFERENCE AMERICAN SOCIETY MECHANICAL ENGINEERING, Washington, 1980, p. 121-129.

ALBUQUERQUE, G. A. C.; MARINHO, M. L. Influência da torta de filtro sobre a adubação nitrogenada em cana de açúcar. Brasil Açucareiro. v.93, n.3, p.38-43. 1979.

ALLEONI, L. R. F.; BEAUClair, E. G. F.; BITTENCOURT, V. C. Produtividade e atributos de crescimento da RB73 5275, em áreas com e sem torta de filtro. STAB Áçucar, Álcool e Subprodutos, v. 14, n.2, p.21-24, Nov./Dez. 1995.

ALMEIDA, J. R. Composição, proporção e aplicação da vinhaça. In: SEMANA DE FERMENTAÇÃO ALCOÓLICA, 3. Piracicaba, ESALQ, 1962. Piracicaba: Instituto Zimotécnico, 1962. p.

ALVES, W. L. Compostagem e vermicompostagem no tratamento de lixo urbano. Jaboticabal: FUNEP, 1996. 46 p.

AMORIN, H. V. Nutrição mineral de leveduras: aspectos teóricos e práticos. In: SEMANA DE FERMENTAÇÃO "JAIME ROCHA DE ALMEIDA", 4., Piracicaba, 1985. Anais. Piracicaba: STAB, 1985. 149p. 
APLICAÇÃO da vinhaça à soqueira da cana-de-açúcar em três anos consecutivos. Boletim Técnico Copersucar, n. 12, p.2-5, 1980.

AREVALO, R. (Ed.) Opções de variedades RB de cana-de-açúcar. In: REUNIÃO TÉCNICA DE VARIEDADES DE CANA-DE-AÇÚCAR, Piracicaba, 1993. Campinas: IAC, 1993. p. 2 - 3.

AZEREDO, D F. de ; MANHÃES, M.S. Adubação orgânica. In: Nutrição e adubação da cana-de-açúcar no Brasil. Piracicaba: IAA/Planalsucar, 1983, p.368.

BEAUCLAIR, E. G. F. Adubação verde e aplicação de matéria orgânica no cultivo da cana-de-açúcar. In: REUNIÃO TÉCNICA AGRONÔMICA: MANEJO E ADUBAÇÃO NA CULTURA DA CANA DE AÇÚCAR. Piracicaba: 1974. Piracicaba: Copersucar, 1984. p.40-47.

BERTON, R. S.; VALADARES, J. M. A. S. Potencial agrícola de compostos de lixo urbano no Estado de São Paulo. O Agronômico, v.43, n.2/3, p. 87-93, 1991.

BOON, D.; SOLSTANPOUR, P. N. Lead, cadmiun and zinc contamination of aspen garden soils and vegetation. Journal Environmental Quality, v.21, p.82-86, 1992.

BRADY, B. Natureza e propriedades dos solos. Rio de Janeiro: Freitas Bastos, 1968. 594p. (Compêndio Universitário)

BROWNE, J.; ZERBAN, F. W. Physical and chemical methods of sugar analysis. 3 edição. New York, John Wiley, 1941. 1353p.

CASTRO, L. J.; GODOY, O. P. Uso da torta de filtro no sulco de plantio de cana-deaçúcar (Saccharum spp.). Brasil açucareiro, v.94, n.5, p.66-76, 1979. 
CESAR, M. A. A.; SILVA, F. C. da. A cana-de-açúcar como matéria prima para a imdústria sucroalcooleira. Piracicaba: CALQ, 1993. 107p.

COlETI, J. T.; BITTENCOURT, V. C.; GIACOMINI, G. M. Torta de filtro rotativo em combinação com diferentes formas de fósforo, com vista à substituição da torta de mamona e de fosfato solúveis em água, na. fertilização da cana planta. Brasil Açucareiro. v.96, n. 6, p. 16-27, 1979.

COlETI, J. T.; CAVAlCANTE Jr., N.; ALBINO, F. E.; KRONKA, P.; PICCIN, C.; NEME, L. H. Influência da torta de filtro, adicionada no sulco de plantio da cana-deaçúcar, sobre os teores de $\mathrm{P}_{2} \mathrm{O}_{5}$ no caldo. STAB Áçucar, Álcool e Subprodutos, v.11, n.2, p.20-24, nov/dez. 1992

COLETI, J. T.; LORENZETTI, J. M.; FREITAS, P. G. R.; GASPARINI, C. T. Redução no uso de fontes minerais na adubação de cana planta, quando do emprego da torta de filtro rotativo. In: CONGRESSO NACIONAL DA STAB, 2, Rio de Janeiro. Anais. Piracicaba: STAB, 1981. v.4, p.203-211.

COLETI, J. T.; LORENZETTI, J. M.; FREITAS, P. G. R.; GASPARINI, G. Redução do uso de fontes minerais na adubação da cana planta quando do emprego de torta de filtro rotativo. STAB Áçucar, Álcool e Subprodutos, v. 1, n. 1. p.46-48, 1982.

COllier, L. S. ; SANTOS, G. A.; PESSANHA, G. G.; PEREIRA, A. L. Efeito do composto de lixo urbano: fontes de $\mathrm{Ca}$ e $\mathrm{Mg}$ e adubação mineral sobre planossolo cultivado com beringela e milho doce em sucessão. In: REUNIÃO BRASILEIRA DE FERTILIDADE DO SOLO E NUTRIÇÃO DE PLANTAS, 20, Piracicaba. Anais. Piracicaba: SBACS, 1992. p. 402 - 403.

COMISSÃO NACIONAL DA ENERGIA (CNE) - BRASIL. Relatório da Assessoria 
Técnica: "Avaliação do Programa Nacional do Álcool", Mai, 1987.

CRAVO, M. S. Composto de lixo urbano como fonte de nutrientes e metais pesados para alface. Piracicaba, 1995. 135 p. Tese (Doutorado). Escola Superior de Agricultura "Luiz de Queiroz, Universidade de São Paulo.

De HAAN, S. Results of municipal wast compost research over more than fifty years at the Institute for Soil fertility at Haren Groningen, Netherlands Journal Agricultural Science. v.29, p.49-61, 1981.

DELGADO, A. A.; CESAR, M. A. A. Determinação de fosfatos em caldo e mosto de cana-de-açúcar. STAB-Açúcar e álcool e subprodutos, Piracicaba, v.3, n.2, p.42-45, 1984

DEMATTÊ, J. L. I. O solo como meio de descarte e degradação de resíduos. In: REUNIÃO BRASILEIRA DE FERTILIDADE DO SOLO E NUTRIÇÃO DE PLANTAS, 20, Piracicaba. Anais. Piracicaba: SBACS, 1992. P.213-251.

DeVleESCHAUEWER, D.; VERDONCK, O.; VAN ASSCHE, P. Phytotoxicity of refuse compost. BioCycle, v.22, n. 1, p.44-46, 1981.

EGREJA FILHO, F. B. Avaliação da ocorrência de distribuição química de metais pesados na compostagem de lixo domiciliar urbano. Viçosa, 1993. 176 p. Dissertação (MS) Universidade Federal de Viçosa.

ENVIROMENTAL PROTECTION AGENCY (EPA). Land Aplication of Municipal Study. Cincinati, 1983. 432p.

EPSTEIN, E ; EPSTEIN, J. I. Public health issues and composting. BioCycle. v. 30, n. 8, 
p. $50-53,1989$.

FAO. Organic recycling in Asia. FAO Soils Bulletin, v.36, p.320-325, 1978.

GLÓRIA, N. A. Emprego da vinhaça para fertilização. Piracicaba: CODISTIL, 1976, $32 \mathrm{p}$.

GLÓRIA, N. A.; MAGRO, A. Utilização agricola dos resíduos de usinas de açúcar e destilarias na Usina da Pedra. In: SEMINÁRIO COPERSUCAR DA AGROINDÚstria AÇUCAREIRA, 4, Águas de Lindóia. Anais. p.163-180, 1977.

GLÓRIA, N. A.; JACINTHO, A. O.; GROSSI, J. M. M.; SANTOS, R. F. Composição mineral das tortas de filtro rotativo. Brasil Açucareiro. v.84 n.3, p.37-44. set./1974.

GOMES, F. P. O húmus, factor de qualidade. Brasil Açucareiro, v.35. n.4, p. 76-78, 1950.

GOMES, F.P. Curso de estatística experimental. São Paulo: Nobel, 1985. 466p.

GROSSI, M. G. L. Avaliação da qualidade dos produtos obtidos de usinas de compostagem brasileira de lixo doméstico atrvés da determinação de metais pesados e substâncias orgânicas tóxicas. São Paulo, 1993. 222p. Tese (Doutorado) - Instituto de Quimica, Universidade de São Paulo.

HERNANDEZ, T. Utilization of municipal wast as organic fertilizers. Suelo Planta, v. 39, p.373-383, 1992

HERNANDO, S. ; LOBO, M. C.; POLO, A. Effect of the application of municipal refuse compost on the physical and chemical properties of a soil. Science Total 
Environmental. V.81, p.589-596, 1989.

HONIG, D. No azucares inorganicos. In: Princípios de tecnologia azucarera México: Continetal, 1969. 3v.

IGUE, T.; ESPIRONELLO, A.; CANTARELlA, H.; NELLI, E. J. Tamanho e forma de parcela experimental para cana-de-açúcar. Bragantia, v.50, n.1, p. 163-180, 1991.

KIEHL, E. J. Fertilizantes orgânicos. Piracicaba: CERES, 1985. 492 p.

KIEHL, E.J. Manual de Edafologia, 22 ed. São Paulo: Ceres, 1968. 262p.

KORNDORFER, G. H.; MARTINS, M. Importância da adubação na qualidade da canade-açúcar. STAB, Açúcar, Álcool e Subprodutos, v.10, n.3, p.26-31, jan./fev., 1992.

LANE, J. H.; EYNON, L. Determination of reducing Sugars by Ferling's solution wvith metlylene Blue indicator. London: Norman Rodger, 1934. 8p.

MAGRO, J. A.; ĞLÓRIA, N. A. Adubação de soqueira de cana-de-açúcar com vinhaça. Complementação com nitrogênio e fósforo. Brasil açucareiro, v.90, n.6, p.31-34, Dez./1977.

MARINHO, M. L.; ALBUQUERQUE, G. A. C.; AMORIN, A. L. C. Influência do nitrogênio, fósforo e potássio no rendimento industrial nos canaviais de Alagoas. In: CONGRESSO BRASILEIRO DE CIÊNCIA DO SOLO, 25, Campinas. Anais. Campinas: SBACS, 1976. 616p. 
MARQUES, T. A.; MARQUES, M. O. Dimensionamento de áreas de sacrifício de vinhaça. Revista Livroceres, v. 12, n.22, p.21-22, 1987.

MATTIAZZO, M. E; GLORIA, N. A.; Composição de tortas de filtro rotativo no transcorrer da safra canavieira. In: CONGRESSO NACIONAL DA STAB, 4., Olinda. Anais. Piracicaba: ACTALAC, 1987. p.186-189.

MAZUR, N.; SANTOS, G. A.; VEllosO, A. C. X. Efeito do composto de resíduo urbano na disponibilidade de fósforo em solo ácido. Revista Brasileira Ciência do Solo, v.7, p.153-156, 1983.

MELO, W. J.; SILVA, F. C.; MARQUES, M. O.; BOARETTO, A. E. Critérios para o uso de residuos sólidos urbanos na agricultura e impactos ambientais. (Compact disc) In: CONGRESSO BRASILEIRO DE CIÊNCIA DO SOLO, 26, Rio de Janeiro, 1997. Anais. Viçosa: SBCS; UFU, 1997.

MESSIAS, A.S.; MORAES, F. A. Emprego do lixo urbano na adubação do milheto. In: REUNIĀO BRASILEIRA DE FERTILIDADE DO SOLO E NUTRIÇÃO DE PLANTAS, 20, Piracicaba. Anais. Piracicaba: SBCS, 1992. p.384-385.

MORAES, S. P.; SELBACH, P. A. Utilização de composto de lixo urbano em solo agricola. In: CONGRESSO BRASILEIRO DE CIÊNCIA DO SOLO, 23. Porto Alegre, Resumos, Piracicaba: SBCS, p.87, 1991.

NUNES JR., D.; CASAGRANDE, A. A. Efeitos das tortas de filtro e de mamona sobre as caracteristicas agroindustriais de vinte variedades de cana-deaçúcar. In: SEMINÁRIO DE TECNOLOGIA AGRONÔMICA, 3., São Paulo. Anais. Piracicaba: Copersucar, 1986. p.349-363. 
NUNES JR., D.; MORELLI, J. L.; NELLI, E. J. Comportamento de variedades de canade-açúcar na presença de tortas de filtro e de mamona. Parte 2. Boletim Técnico Copersucar, v.41, n.88, p.3-12, Abr. 1988.

PARRA, M. S.; OLIVEIRA, E.L. de; COSTA, A. Potencial agronômico do composto de lixo urbano. In: CONGRESSO BRASILEIRO DE CIÊNCIA DO SOLO, 26, Rio de Janeiro, 1997 Resumos, Campinas: SBCS, p.494, 1997.

PEREIRA NETO, J. T. ; STENTIFORD, E. I. Aspectos epidemiológicos da compostagem. BioCycle v.27, n.4, p. 1-6, 1992.

PEREIRA NETO, J. T. Alguns aspectos sobre o estado do gerenciamento dos residuos sólidos no Brasil. In: SIMPÓSIO LUSO BRASILEIRO DE ENGENHARIA SANITÁRIA AMBIENTAL, 5. Lisboa, 1989. Anais. Lisboa; 1989. p.397-418.

PETRUZZELLI, G. Recycling wastes in agriculture. Heavy metal bioavailability. Agricultural. Ecosyst. Environmetal., v.27,n.4, p.493-503, 1989.

POLO, A.; ANDREUX, F.; CERRI, C.C.; LOBO, M. del C. Resíduos orgânicos da agroindústria canavieira. STAB, Açúcar, Álcool e Subprodutos, v.6, n.4/5, p. 53-56, mar./jun., 1988.

PRASAD, M. The effect of filter-press mud on the avaliability of macro and micronutrients. In: CONGRESS INTERNACIONAL SOCIETY OF SUGAR TECHNOLOGISTS, 15, Durban. 1974. Proceeding, Durban: ISSCT, 1974. p.13-29.

PURVES, D. ; MACKENZIE, J.E. Effects of applications of municipal compost on uptake of copper, zinc and boron by garden vegetables. Plant Soil, v.39, n. 1, p.361371, 1973. 
RAIJ, B. van; SILVA, N. M. da; BATAGLIA, O. C.; QUAGGIO, L. A.; HIROCE, R.; CANTARELla, H.; BELlinAZZI, JR. R.; DECHEN, A. R.; TRANI, P. E. Recomendações de adubação paa o Estado de São Paulo. Campinas, Instituto Agronômico, 1985. (IAC-Boletim Técnico). 107p

RAIJ, B. V.; QUAGGIO, J. A. Métodos de análises de solos para fins de fertilidade. Boletim Técnico, n.81, p.1-31, 1983.

RESENDE, A. A. P. Estudo e avaliação de um processo de reciclagem e compostagem dos resíduos sólidos urbanos. Belo Horizonte, 1991. 151 p. Dissertação (Mestrado) Universidade Federal de Minas Gerais.

RICHARD, T. Clean compost production. BioCycle. v. 31, n. 2, 1990, p. 46 - 47.

SANTANA FILHO, S.; CAROSO, I. M.; PEREIRA NETO, J.T. Utilização de composto orgânico de lixo urbano na recuperação de áreas degradadas. In: (Compact disc) CONGRESSO BRASILEIRO DE CIÊNCIA DO SOLO, 26., Rio de Janeiro 1997. Viçosa: SBCS; UFV, 1997.

SANTOS, C. E. R.; STAMFORD, N. P. Efeito do composto urbano e da adubação fosfatada suplementar na correção da acidez e na disponibilidade do fósforo. In: CONGRESSO BRASILEIRO DE CIÊNCIA DO SOLO, 24., Recife, 1993. Resumos. Recife: SBCS, 1993. v.3, p.243-244

SANTOS, C. E R. S.; SANTOS, J R.; STAMFORD, N. P. Efeito do composto urbano e do fósforo em leucema inoculada com Rhizobium loti micorriza vesicular arbusculares. In: REUNIÃO BRASILEIRA DE FERTILIDADE DO SOLO E NUTRIÇÃO DE PLANTAS, 21., Petrolina, 1994 Anais, Recife: SBACS, p.248-249, 1994.

SANTOS, J. R.; STAMFORD, N. P. Efeitos da adição de composto urbano e níveis de 
fósforo na forma de fosfogesso, no rendimento da leucena (Leucaena leucocephala (Lam.) de wit.) e características químicas de um LVA-Distrófico. In: CONGRESSO BRASILEIRO DE CIÊNCIA DO SOLO, 23, Porto Alegre, 1991. Resumos. Porto Alegre: SBCS, 1991. v.1, p.112.

SCHENEIDER, F. ed. Sugar analysis methods. Peterborough: ICUMSA, 1979. $256 \mathrm{p}$.

SILVA JR., J. F. Efeitos da aplicação de fontes de fósforo na clarificação do caldo de cana. In: SEMINÁRIO COPERSUCAR DA AGROINDÚSTRIA AÇUCAREIRA, 4, Piracicaba. Anais. Piracicaba: Copersucar, 1975. p.339-353.

SILVA, G. M. A.; GURGEL, M. N. A. Aplicação de vinhaça como fertilizante em canade-açúcar em solo LE-fase arenosa. In: CONGRESSO NACIONAL DA STAB, 1., Rio de Janeiro., 1981. Anais. Piracicaba: STAB, 1981.

SIMÕES NETO, D. E.; COSTA, E. F. S.; SOBRAL, A. F.; SILVA, J. C. C. Efeito da torta de filtro e de mamona na produtividade agrícola da cana de açúcar (Saccharum spp.). In: CONGRESSO NACIONAL DA STAB, 4, Olinda. Anais. Piracicaba: ACTALAC, 1987. p.186-189.

STURION, A. C.; FERNANDES, A. C. Análise direta da cana-de-açúcar pelo método para prensa hidráulica. Boletim Técnico COPERSUCAR. n.8, p. 12-15 1979.

TANIMOTO, T. The press method of cane analysis. Hawaii Pers: 1964. p.133-150

WALKER, J. M.; O'DONNELL, M. J. Comparative assessment of MSW characteristics. BioCycle. v. 32, n.8, p. 65 - 69, 1991. 
XIN, T. H.; TRAINA, S. J.; LOGAN, T. J. Chemical properties of municipal solid waste compost. Journal Environment Quality. v. 21, p. 318 - 329, 1992.

ZUCCONI, F.; FORTE, M.; MONACO, A.; DeBERTOLDI, M. Biological evaluation of compost maturity. BioCycle. v.22, n. 4, p. 27 - 29, 1981. 